\title{
Acinetobacter baumannii Resistance: A Real Challenge for Clinicians
}

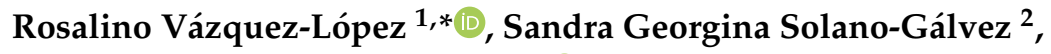 \\ Juan José Juárez Vignon-Whaley ${ }^{1}{ }^{\mathbb{C}}$, Jorge Andrés Abello Vaamonde ${ }^{1}{ }^{\mathbb{D}}$, \\ Luis Andrés Padró Alonzo ${ }^{1}$, Andrés Rivera Reséndiz ${ }^{1}$, Mauricio Muleiro Álvarez ${ }^{1}$, \\ Eunice Nabil Vega López ${ }^{3}$, Giorgio Franyuti-Kelly ${ }^{3}{ }^{1}$, Diego Abelardo Álvarez-Hernández ${ }^{1}{ }^{1}$, \\ Valentina Moncaleano Guzmán ${ }^{1}$, Jorge Ernesto Juárez Bañuelos ${ }^{1}$, José Marcos Felix ${ }^{4}$, \\ Juan Antonio González Barrios ${ }^{5} \mathbb{D}$ and Tomás Barrientos Fortes ${ }^{6}$ \\ 1 Departamento de Microbiología del Centro de Investigación en Ciencias de la Salud (CICSA), FCS, \\ Universidad Anáhuac México Norte, Huixquilucan 52786, Mexico; juan.juarezvi@anahuac.mx (J.J.J.V.-W.); \\ jorge.abellova@anahuac.mx (J.A.A.V.); luis.padro@anahuac.mx (L.A.P.A.); \\ andres.riverare@anahuac.mx (A.R.R.); mauricio.muleiroal@anahuac.mx (M.M.Á.); \\ diego.alvarez@anahuac.mx (D.A.Á.-H.); valentina.moncaleano@anahuac.mx (V.M.G.); \\ jorge.juarez@anahuac.mx (J.E.J.B.) \\ 2 Departamento de Microbiología y Parasitología, Facultad de Medicina, Universidad Nacional Autónoma de \\ México, Ciudad de Mexico 04510, Mexico; sgsolano@comunidad.unam.mx \\ 3 Medical IMPACT, Infectious Diseases Department, Mexico City 53900, Mexico; \\ eunicevega.mi@gmail.com (E.N.V.L.); giorgio.franyuti@gmail.com (G.F.-K.) \\ 4 Coordinación Ciclos Clínicos Medicina, FCS, Universidad Anáhuac México Norte, \\ Huixquilucan 52786, Mexico; jose.felix@anahuac.mx \\ 5 Laboratorio de Medicina Genómica, Hospital Regional “1 $1^{\circ}$ de Octubre", ISSSTE, Av. Instituto Politécnico \\ Nacional 1669, Lindavista, Gustavo A. Madero, Ciudad de Mexico 07300, Mexico; \\ jantgonzalez@issste.gob.mx \\ 6 Dirección Sistema Universitario de Salud de la Universidad Anáhuac México (SUSA), \\ Huixquilucan 52786, Mexico; tbarrien@anahuac.mx \\ * Correspondence: rosalino.vazquez@anahuac.mx or vazquezrosalino@yahoo.com; \\ Tel.: +52-56-270210 (ext. 7302)
}

Received: 14 December 2019; Accepted: 5 February 2020; Published: 23 April 2020

Abstract: Acinetobacter baumannii (named in honor of the American bacteriologists Paul and Linda Baumann) is a Gram-negative, multidrug-resistant (MDR) pathogen that causes nosocomial infections, especially in intensive care units (ICUs) and immunocompromised patients with central venous catheters. A. baumannii has developed a broad spectrum of antimicrobial resistance, associated with a higher mortality rate among infected patients compared with other non-baumannii species. In terms of clinical impact, resistant strains are associated with increases in both in-hospital length of stay and mortality. A. baumannii can cause a variety of infections; most involve the respiratory tract, especially ventilator-associated pneumonia, but bacteremia and skin wound infections have also been reported, the latter of which has been prominently observed in the context of war-related trauma. Cases of meningitis associated with $A$. baumannii have been documented. The most common risk factor for the acquisition of MDR A baumannii is previous antibiotic use, following by mechanical ventilation, length of ICU/hospital stay, severity of illness, and use of medical devices. Current efforts focus on addressing all the antimicrobial resistance mechanisms described in A. baumannii, with the objective of identifying the most promising therapeutic scheme. Bacteriophage- and artilysin-based therapeutic approaches have been described as effective, but further research into their clinical use is required

Keywords: Acinetobacter baumannii; antibiotic resistance; septicemia 


\section{Introduction}

The history of the genus Acinetobacter dates back to the 20th century, when the Dutch microbiologist Beijernick described an organism called Micrococcus calcoaceticus that was isolated from the soil by means of a medium enriched with calcium acetate [1,2].

The current genus designation, Acinetobacter, refers to the Greek concept "Akinetos", which means "not mobile" [2]. Brisou and Prévot introduced this concept during 1954, with the objective of differentiating mobile from non-mobile organisms, mainly those belonging to the Achromobacter genus [3]. Although Acinetobacter is still described as a non-mobile microorganism, most strains exhibit "spasmodic" motility [4]. The nutritional and biochemical properties of Diplococcus mucosus, Micrococcus calcoaceticus, Alcaligenes Haemolysans, Mima polymorpha, Moraxella lwoffi, Herellea Vaginicola, Bacterium anitratum, Moraxella lwoffi var. Glucidolytica, Neisseria winogradskyi, Achromobacter anitratus, and Achromobacter mucosus, among others, were analyzed; concluding that all of them belonged to a common genus. In this way, the concept of Acinetobacter was introduced, but the subsequent subclassification into different species based on the phenotypic characteristics was not established at this point [4]. These findings resulted in the official recognition of Acinetobacter genus by the Taxonomy of Moraxella and Allied Bacteria Subcommittee during 1971 [5]. Later, in 1974, the genus was included in Bergey's Manual of Systematic Bacteriology, along with the description of a single species: Acinetobacter calcoaceticus [5].

The Acinetobacter genus morphology consists of Gram-negative coccobacilli widely distributed in nature. Microorganisms included in it are characterized by being strictly aerobic, non-fermenting, nonfastidious, not mobile, catalase-positive, and oxidase-negative bacteria, with a $39 \%$ to $47 \%$ content of guanine-cytosine (GC) in their DNA sequence [2]. Within the genus, there are more than 50 species, which are mostly nonpathogenic environmental organisms [6]. However, among infectious species, $A$. baumannii has been described as the most virulent one [7], followed by A. calcoaceticus and A. lwoffii [8]. The phylogenetic description of the genus continuous to develop. Touchon et al. used 950 core protein families of the genus to build its phylogenetic tree with significant statistical support. In it, A. brisouii and A. nectaris are positioned as the taxa branching deeper in the genus. After this split, two large groups of taxa emerge, the first including A. baumannii, A. parous, and A. baylyi, while the second one includes A. lwoffii, A. johnsonii, and A. guillouiae, among others. [9] The metabolic and ecological diversity of the species within the genus could be related to its ancient history. Touchon et al. suggested that its last common ancestor was a close contemporary of the last common ancestor of Enterobacteriaceae, which in turn emerged over 500 million years ago [10].

The first identification assay for Acinetobacter species was based on their biochemical profile. The use of molecular methods, specifically DNA-DNA hybridization [11], has been used to establish the identity of at least 33 different genospecies of Acinetobacter [12]. Among these genospecies, Acinetobacter calcoaceticus (genospecies 1), Acinetobacter baumannii (genospecies 2), Acinetobacter genomic species 3 (genospecies 3), and Acinetobacter genospecies 13TU (Acinetobacter genomic species 13), share phenotypic characteristics that make them difficult to differentiate. As a result, the above-mentioned have been grouped in the Acinetobacter baumannii-calcoaceticus (ACB) complex. Identification limited to the ACB complex can be misleading, as the genospecies in it differ in their biological and pathological characteristics. This remark must be taken into account, as A. baumannii (genospecies 2) represents the greatest clinical significance of the complex, while, for example, A. calcoaceticus (genospecies 1 ) has been considered to be an environmental pathogen rarely implicated as a cause of severe disease [13].

$\mathrm{ABC}$ organisms are characterized by having intrinsic antimicrobial resistance mechanisms that can be expressed constitutively or in response to antibiotic pressure. An analysis of susceptibility data for ABC organisms between 1995 and 2004 confirmed an increase in the percentage of resistance to all antimicrobial agents in four major classes of antimicrobials: fluoroquinolones (50-73\% nonsusceptible), aminoglycosides (19-31\% nonsusceptible), $\beta$-lactams (39-66\% nonsusceptible), and carbapenems (9-39\% nonsusceptible) [14]. Carbapenem resistance increase is of important concern, as this type of antimicrobial is often considered the last line of defense in treating resistant ABC. Of greater concern is 
the fact that a higher degree of bacterial resistance to antibiotics causes multiple classes of antimicrobial agents to become ineffective, this phenomenon is observed in bacteria called "multi-drug resistance" or "MDR" [15]. When reviewing the analysis of susceptibility data for ABC mentioned above, the authors considered MDR isolates as those with diminished susceptibility to all tested agents within three of the four major classes of antibiotic agents. They confirmed a significant increase in MDR ABC isolates (14\% in 1995 to $26 \%$ in 2004) [14,15].

The most common MDR pathogens have been grouped in the acronym "ESKAPE" which stands for Enterococcus faecium, Staphylococcus aureus, Klebsiella pneumoniae, Acinetobacter baumannii, Pseudomona aeruginosa, and Enterobacter cloacae. The World Health Organization (WHO) declared that A. baumannii is one of the most serious of the ESKAPE organisms that effectively escape the effects of antibacterial drugs [16].

During the 1970s, clinical isolates of A. baumannii were susceptible to commonly used antibiotics, such as ampicillin, gentamicin, chloramphenicol, and nalidixic acid. However, in the late 1970s, it emerged as a significant nosocomial pathogen, mainly associated with the use of broad-spectrum antibiotics in hospitals [12]. Today, it shows resistance for most first-line antibiotics. Colistin and tigecycline remain the only antibiotics active against it and have become the last resort of treatment for multidrug-resistant (MDR) A. baumannii; however, colistin-resistant strains have been reported in different regions from around the world [17].

The increasing rates of antibiotic resistance can be attributed to multiple causes. There is a direct relationship between the emergence of resistant strains and the magnitude of antibiotic consumption [18]. Resistance mechanisms can be transmitted from one bacterium to another either longitudinally, when inherited from relatives, or horizontally, by means of plasmids. The latter may result in the transference of resistance among different species [19]. Inappropriate prescribing is also a determining phenomenon; studies have described that $30 \%$ to $50 \%$ of antimicrobial therapies are incorrectly prescribed $[20,21]$. Massive agricultural use of antibiotics, especially as growth supplements in livestock, is also a major concern; farm animals transfer antibiotics and resistant bacteria to humans through the intake of their meat, increasing the rate of antibiotic-resistant strains causing infections in humans. Another cause is the slow development of new antibiotics; the availability and low cost of antimicrobials has led to a considerable reduction of investment into new alternatives by the pharmaceutical industry [22].

Li-Kuang and collaborators analyzed clinical isolates of A. baumannii. $73.6 \%$ of such isolates were found to be resistant to quinolones (ciprofloxacin and levofloxacin), $71.3 \%$ to sulfonamides, and more than half (50-70\%) to cephalosporins (cefazidime and cefepime), b-lactam/beta-lactamase inhibitor combinations (tazobactam-piperacillin), and carbapenems (doripenem, imipenem, and meropenem). It should be noted that just $26.7 \%$ demonstrated resistance against the glycycline antibiotic tigecycline. No resistance to colistin was observed [23].

There are numerous mechanisms through which antibiotic resistance develops. According to Gordon and Warehan, the most documented include alteration in the target sites, failure in the degradation-specific enzymes, perfusion defects and modification in multidrug effusion pumps, mainly associated with, among others [24].

With the objective of limiting the consequences of MDR microorganisms and developing better therapeutic approaches, the WHO in its report "Global Strategy for Containment of Antimicrobial Resistance" described two pillars of action. The first emphasizes preventing the dissemination of bacterial resistance, and the second, avoiding the accelerated emergence of new forms of resistance [25].

Early identification of patients exposed to risk factors favors the effectiveness of therapeutic outcome. In the particular case of nosocomial infections associated with imipenem-resistant $A$. baumannii strains, Lee and collaborators demonstrated the following as significant risk factors: previous intensive care unit (ICU) stay (OR, 21.54; 95\% CI, 10.73 to 43.23) and prior exposure to third-generation cephalosporins (OR, 2.11; 95\% CI, 1.13 to 3.95) or imipenem (OR, 9.18; 95\% CI, 3.99 to 21.13), increased time at risk or days spent from admission to positive-culture date for A. baumannii-positive patients 
(OR, 1.02; 95\% CI, 1.002 to 1.03), and age (OR, 1.03; 95\% CI, 1.01 to 1.05) [26]. Lemos and collaborators described male sex as a significant risk factor for MRAB-C bacteremia $(p<0.001$; OR 3.39, 95\% CI $(1.76-6.54))$ [27].

Other studies have introduced advanced age, mechanical ventilation, renal failure, and prolonged hospital stay as important risk factors for the development of nosocomial A. baumannii infection [28,29]. Regarding risk factors for mortality, inappropriate empirical antibiotic therapy, high APACHE II score, severity of underlying disease, time of stay in the ICU, presence of fever and/or hypotension at the time blood sample for culture was obtained, and mechanical ventilation have been reported as significant. It must be noted that a high mortality rate has been associated with infections caused by carbapenem-resistant $A$. baumannii strains [30-33].

Once thought to be benign, A. baumannii is now considered a healthcare threat, mainly because of its potential to acquire multidrug, extensive drug, and even pandrug resistance phenotypes at previously unforeseen rates [34-36].

Infections caused by A. baumannii account for $\sim 2 \%$ of all healthcare-associated infections in the United States and Europe; [37] however, these rates are twice as high in Asia and the Middle East [38]. Although infection rates are lower than those caused by other Gram-negative pathogens [34], 45\% of all isolates are considered to be MDR, a rate up to four times higher when compared to other Gram-negative pathogens, such as P. aeruginosa and K. pneumoniae. In particular, MDR rates reach about $70 \%$ in Latin America and the Middle East [35]. As a consequence to these concerning statistics, the WHO has included carbapenem-resistant $A$. baumannii in the "critical group" of all bacteria that represent greatest threat to human health, prioritizing research and development efforts for new antimicrobial treatments [39].

\section{Pathogenicity Mechanisms}

All the precise mechanisms involved in the establishment and progression of A. baumannii infection are unclear; however, some have been described.

Genomic studies comparing susceptible and resistant $A$. baumannii strains with the environmental strain, Acinetobacter baylyi, have identified genes involved in pilus biogenesis, iron uptake and metabolism, quorum sensing, and a type IV secretion system as making up part of the organism's "virulome" [40].

The glicosiltranspherase (LpsB), one of the pathogenicity mechanisms identified in A. baumannii, is implicated in lipopolysaccharide (LPS) biosynthesis [41], a component of Gram-negative bacteria that is released after lysis or multiplication [42]. However, A. baumannii synthesizes lipooligosaccharide (LOS), which includes only core oligosaccharide and lipid A, rather than LPS, which would have an additional region of O-polysaccharide [43,44].

In most Gram-negative bacteria, lipid A is hexa-acylated. In contrast, A. baumannii lipid A is predominantly acylated hepta [44]; such hepta-acylation confers to A. baumannii resistance to cationic antimicrobial peptides (CAMPs) in vertebrate mucosal secretions and consequently allows desiccation survival, this being an important virulence factor of A. baumannii [44]. Outer membrane protein PagP is responsible for transferring the extra palmitoyl group to lipid A on Gram-negative bacteria, and particularly does so upon exposure to stressful factors [45]. However, A. baumannii lacks a gene that encodes a PagP homolog, so the synthesis of hepta-acylated lipid A molecules occurs independently of the PagP mechanism [44].

Lipid A confers a potentially toxic function and induces the pro-inflammatory cytokine expression in human monocytes mediated by the CD14 receptor, as well as TLR-2 and TLR-4 [46-48]. According to Erridge et al., the extent to which TLR-2 contamination with surface lipoproteins contributes to in vitro stimulation is debatable $[47,48]$.

Additionally, A. baumannii expresses the phospholipase D, important for its development in human serum, and phospholipase C, which increases its cytotoxicity to epithelial cells [49,50]. 
A. baumannii is also characterized by a capsular polysaccharide, which decreases its adhesion to hydrocarbons, increases adhesion to epithelial cells, and facilitates protection against phagocytosis. The capsule consists of L-rhamnose, D-glucose, D-glucuronic acid, and D-mannose, polymerized and assembled by the genes $p t k$ and eps $A$ [51].

Outer membrane proteins (Omp) are also virulence key factors of A. baumannii, particularly OmpA, which is a major component of outer membrane vesicles [52,53]. This protein is directed towards an epithelial cell, adheres to it, and, after being taken in and reaching the nucleus, induces apoptosis through a process dependent on caspase- 3 and mediated by the activation of upstream initiators such as caspase- 8 and caspase-9 [54-56]. Purified OmpA provokes a $\mathrm{Th}_{1}$-mediated immune response [57] and upregulates inducible nitric oxide synthase (iNOS) via a Toll-like receptor (TLR)-2-mediated pathway [58].

Mitochondrial changes are also initiated, leading to the translocation of cytochrome $\mathrm{C}$ into the cytosol and the initiation of an apoptotic cascade [55]. Choi et al. have suggested that OmpA also degrades chromosomal DNA by DNAse I-like enzymatic activity [59]. OmpA has been also described as an important complement-regulator-acquiring surface protein, allowing $A$. baumannii to evade complement attack [60]. This outer membrane protein plays a partial role in the development of biofilms on plastic, but is required for attachment to fungal filaments and epithelial cells [61].

Acinetobacter baumannii readily adheres both to biological and abiotic surfaces, on which it is able to form biofilms [62-64]. The disruption of the csuC and csuE open reading frames (ORFs) has been linked to A. baumannii strains that lack pili and biofilm formation, suggesting that these genes are involved in both virulence factors [65]. Appendages involved in its synthesis are type IV pili, flagella, curli, and fimbriae [40]. There is evidence to suggest that biofilms increase A. baumannii survival time in dry environments (these organisms can live for an average of 20 days at a relative humidity of $31 \%$ ) [66]. Desiccation resistance, which is the ability to maintain viability under dry conditions, varies among clinical isolates of $A$. baumannii, with some isolates remaining viable for almost 100 days. Such ability is multifactorial and not yet fully defined $[34,67,68]$. It must be noted that biofilm formation could be associated with increased resistance against immune host response [30].

For the maturation of such biofilm, a protein associated with biofilm (BAP) located in its external membrane is required; it provides greater thickness and volume, in this manner facilitating intercellular adhesion [69]. A. baumannii contains a locus that encodes proteins which synthesize cell-associated poly- $\beta-(1-6)-N$-acetylglucosamine (PNAG) polysaccharide; PNAG is a key component to securing the organism's stability in stressful environments [70].

Initial adhesion depends on functional fimbriae and pili, followed by the production of exopolysaccharide, which suppresses the activity of neutrophils and contributes to serum resistance. Variation in the expression of factors involved in these and other pathways may account for the differing capacity of strains to colonize or infect the host environment [24]. Once adhered, A. baumannii invades and induces apoptosis of eukaryotic cells [55], a property attributed to the activity of OmpA (Omp36), which is trafficked to both the mitochondria and the nucleus $[54,55]$.

Human multidrug-resistant $A$. baumannii strain is characterized, as many other Gram-negative bacteria, by having a $\mathrm{N}$-acylhomoserine lactone (AHL)-mediated quorum-sensing regulatory mechanism, which is known to be involved in biofilm formation [71], host-cell gene expression modification [72] and non-ribosomal peptide synthase (NRPS) encoding, which in turn results in toxins, siderophores, antibiotics, and pigments [40].

Furthermore, bacterial pathogenicity is closely related to the capacity to use specific iron acquisition strategies [73], such as the production of aerobactines and iron-dependent external membrane proteins [74]. Siderophores/hemophores, high-affinity iron molecules released outside of cells that compete with host binding proteins for essential iron, have been identified in human multidrug-resistant A. baumannii strains [74]. These are essential for the survival and growth of the pathogen under low-iron-content circumstances $[40,73]$. 


\section{Antibiotic Resistance Shown by A. baumannii}

Different A. baumannii strains are endemic to different regions around the world [75]. MDR strains survive antimicrobials by means of various mechanisms, each of them specific against particular types of drugs.

\section{Aminoglycosides}

Aminoglycosides bind to the RNA $16 \mathrm{~S}$ of the ribosomal 30S subunit. The most studied mechanism of resistance to this type of antibiotic in A. baumannii strains is the production of aminoglycoside modifier enzymes. Three different functional groups of modifier enzymes are known, which include aminoglycoside acetyltransferases (AAC), for example AAC (6')-Ih (which also confers resistance to gentamicin and amikacin) [76,77], aminoglycoside phosphotransferases (APH), for example APH (3')-IA (which confers resistance to gentamicin) [78], and aminoglycoside adenililtransferases (ANT), for example ANT (2")-IA [77]. The production of RNA 16S ribosomal methyltransferase, especially ArmA, the first of its type to be discovered in a clinical isolate, is a mechanism of resistance to aminoglycosides that appears to be emerging [79]. A. baumannii strains that produce ArmA are highly resistant to gentamicin, amikacin, and tobramycin [80,81].

On the other hand, a study conducted in Korea by Choy et al. demonstrated the presence of aminoglycoside-resistance genes in 61 out of 75 Acinetobacter isolates from two Korean hospitals. A. baumannii isolates carrying the genes encoding aminoglycoside-modifying enzymes ant(3")-Ia, aac $\left(6^{\prime}\right)-\mathrm{Ib}$, aph (3')-1a, aac(3)-Ia, and aph(3')-VI, and 16S ribosomal RNA (rRNA) methylase ArmA were resistant to amikacin, gentamicin, isepamycin spectinomycin, streptomycin, and tobramycin [82].

\section{Carbapenems}

Carbapenems have the broadest spectrum among all $\beta$-lactams and are mainly used as a treatment in infections caused by Gram-negative bacteria [83]. Overexpression of the carbapenem-hydrolyzing oxacillinase (OXA)-51-like-B-lactammase $[84,85]$ and ArmA RNA $16 \mathrm{~S}$ ribosomal methyltransferase are among the mechanisms that confer resistance to carbapenems among A. baumannii strains [86].

Increasing emergence of carbapenem resistance, frequently mediated by production of Ambler's class D $\beta$-lactams (OXA), in A. baumannii is a major concern $[87,88]$. Many of them are found as part of integrons $[89,90]$. A. baumannii can present intrinsic chromosomal OXA-51-like, and four additional groups of OXA acquired carbapenemases, including OXA-23, 24 (OXA-40-like), -58-like, and -123-like [91]. OXA-23 has been associated with greater dissemination and production of carbapenem resistance with clinical consequences [92]. It has been documented that OXA-24 has moderate hydrolytic activity against carbapenems [93].

A. baumannii produces the group of chromosomally encoded carbapenemases OXA- 51 in a basal manner, so it is not a cause of resistance by itself. However, if the transposition of ISA $b a 1$ or ISA $b a 9$ occurs upstream of the gene of the group OXA-51, overexpression is initiated [94,95].

It should be noted that the OXA group of carbapenemases confer resistance to oxacillin and carbapenems, but not to cephalosporins. However, in most clinical isolates, the acquired carbapenem resistance was mediated by the presence of blaOXA genes, and resistance to cephalosporins was already present due to other bla type gene like blaAmpC [96]. Non-OXA carbapenemases have also been reported in A. baumannii, although they are more frequent in Enterobacteriaceae. For example, Ambler's class B metallo- $\beta$-lactamases have been identified. In this classification, the NDM (New Delhi metallo- $\beta$-lactamase) group of enzymes includes IMP (imipenemases), VIM (Verona imipenemase), and SIM (Seoul imipenemase), which are types of metallo- $\beta$-lactamases not common in A. baumannii strains [97-99].

Fernández-Cuenca et al. suggested that the reduced expression of penicillin-binding protein (PBP) 2 is also an important mechanism involved in the acquisition of carbapenem resistance [100]. 


\section{Fluoroquinolones}

A. baumannii's fluoroquinolone resistance mechanism consists of substitutions in the quinolone resistance-determining regions (QRDRs) of DNA gyrase and DNA topoisomerase IV, which interfere with the fluoroquinolones' union to their target proteins [86]. Overexpression of efflux active pumps can also cause moderate resistance by itself and increase resistance in strains with RDRQ substitutions [101].

\section{Cephalosporins}

Many of the clinical isolates of A. baumannii are resistant to cephalosporins. A new Ambler's class $\mathrm{C} \beta$-lactamase was found in a clinical isolate recovered from a hospital in Cleveland $\mathrm{OH}$, USA. This enzyme, also expressed in Escherichia coli DH10B, demonstrated greater resistance against ceftazidime and cefotaxime than cefepime. After a phylogenetic analysis of this new enzyme and other class $C$ $\beta$-lactamases described in A. baumannii, Acinetobacter pittii, and Oligella urethralis, it was found to define a unique class of class $C$ enzymes. In this manner, a uniform designation was proposed for these cephalosporinases: Acinetobacter-derived cephalosporinases (ADC). The new enzyme was named ACD-7 $\beta$-lactamase, as six related cephalosporinases had been described before [102]. Unlike most chromosomally produced class C $\beta$-lactamases, A. baumannii AmpC ADC-7 cannot be induced by cefoxitin [102]. According to Lopes et al., the ADC expression can be increased if there is an insertion of the ISA $b a 1$ or ISA $b a 125$ sequence upstream of the ADC gene, so there is a higher promoter activity compared to the activity of the native promoter $[103,104]$. As a result, an elevation of the minimum inhibitor concentrations of the different cephalosporins is required, except cefepime, which is not a substrate of the $\beta$-lactamase class $C$, including ADC. It has been reported that there are strains of $A$. baumannii that produce extended-spectrum class $C \beta$-lactamases such as ADC-33, which do confer resistance against cefepime, as well as against other cephalosporins [105].

\section{Sulbactam}

PBP2 (penicillin-binding protein) has been shown to have the highest affinity for penicillin and beta lactamase inhibitors. Sulbactam binds to A. baumannii's PBP2 to initiate an effect against the microorganism [106]. The resistance of A. baumannii to sulbactam is associated with a reduced expression of PBP2 [100]. Additionally, it has been demonstrated that the role of $\beta$-lactamase synthesis encoded in the gene BlaTEM-1, contributes to sulbactam resistance in A. baumannii [107].

It is important to take into account that the potential therapeutic usefulness of sulbactam has been reported as superior compared to other $\beta$-lactamase inhibitors, such as clavulanic acid and tazobactam. $\beta$-lactamase inhibitors have intrinsic activity but are not capable of enhancing the activity of $\beta$-lactams against $A$. baumannii [108].

\section{Rifampicin}

Rifampicin binds to the active site of bacterial RNA polymerase, inhibiting the transcription process. The mechanism of evasion to this medicine is the substitution of amino acids in the $\beta$-subunit of this target protein. Elevated minimum inhibitory concentrations in A. baumannii have been associated with rpoB mutations [109]. In addition, active efflux and enzymatic modification by the ADP ribosyltransferase of rifampicin (ARR-2) contribute to resistance against rifampin in A. baumannii strains $[109,110]$.

\section{Tetracyclines}

Resistance against tetracyclines is mediated by various mechanisms, including active efflux of the antimicrobial mediated by resistance proteins in the bacterial cytoplasmic membrane and inhibition of ribosomal and tetracycline binding [111].

Tigecycline, which was designed to prevent most resistance mechanisms, is prone to effusion generated by the resistance-nodulation-division (RND)-type efflux pumps produced by most clinical 
isolates of A. baumannii [112]. Hornsey et al. described high MICs of tigecycline being correlated with the elevated expression of ade $A B C$. Clinical isolates resistant to tigecycline, when having their $a d e B$ interrupted, once again showed full susceptibility to this antibiotic [113].

\section{Polymyxins}

As antibiotic resistance increases among Gram-negative bacteria, especially P. aeruginosa, A. baumannii, and K. pneumoniae, effective antimicrobial therapeutic approaches have been limited. Now, the effectiveness of the clinical application of colistin, a polymyxin that was discovered more than 50 years ago, is being re-evaluated [114]. According to the CDC (Centers for Disease Control and Prevention of the U.S. Department of Health and Human Services), because polymyxins are generic drugs, there is limited updated data on their proper dosing [115].

Colistin (Polymyxin-E) interacts with lipopolysaccharide's (LPS) lipid A. Its modification results in acquired polymyxin resistance. The most commonly reported modification method is the addition of a phosphoethanolamine residue to the hepta-acylated form of lipid A, removing negative charges and lowering the affinity LPS for polymyxins [116,117]. Another mechanism through which $A$. baumannii develops such resistance is by complete loss of the initial LPS [118]. According to Biswas et al., the combination therapy of polymyxin-rifampicin is being studied for the treatment of MDR Gram-negative bacteria. In most studies, the colistin-rifampicin combination has shown a $100 \%$ synergy when facing MDR A. baumannii [119].

\section{Resistance Genes}

The various identified resistance genes in A. baumannii can be constitutive or acquired by means of integrons, transposons, and plasmids. They encode both the enzymes that modify the antibiotic molecules and the modifications of the antibiotic target sites. These genes also code for the efflux pump proteins and porin channels of the cell membrane, both systems related to the decrease in the intracytoplasmic concentration of the antibiotic. [120]. The AdeB gene controls the expression of AdeB proteins, which are members of the resistance-nodulation-division (RND) efflux pump superfamily, thus regulating the bacterial internal drug efflux pump that plays a significant role in drug resistance [121,122]. Another study revealed that mutations in the genes of lipid A biosynthesis (LpxA, LpxC, and LpxD) may lead to significant increase in the resistance to colistin. Additionally, extended-spectrum $\beta$-lactamase genes blaTEM, blaSHV, and blaCTX-M have been described among $A$. baumannii [123]. Most clinical isolates (98\%) analyzed by Benmahmod et al. carried blaOXA-23-like and blaOXA-51-like simultaneously. In such isolates, coexistence of carbapenem-hydrolyzing $\beta$-lactamases also was detected (blaKPC, bla GES, blaNDM, blaSIM, blaVIM, blaIMP) [124].

\section{Treatment}

The World Health Organization (WHO) has considers antibiotic multiresistance to be one of the three greatest health threats of the century [125].

Treatment against $A$. baumannii infections is limited by the recurrent antimicrobial resistance rate. In particular, the ACB complex (A. calcoaceticus, genospecies $1 ; A$. baumannii, genospecies $2 ; A$. genomic species 3, genospecies 3; $A$. genospecies $13 \mathrm{TU}$, genospecies 13 ) is responsible for approximately $80 \%$ of infections and has shown resistance to all Gram-negative antimicrobial agents [126]. The antimicrobial resistance that characterizes $A$. baumannii, is related to its capacity to react rapidly to challenges issued by antimicrobials. Thus, the widespread use of antibiotic therapies in healthcare facilities, especially extended-spectrum cephalosporins and quinolones, represents an important factor to be considered [127]. In vitro susceptibility tests have become a useful tool for determining the adequate antibiotic treatment [128]. A.-baumannii-associated nosocomial infections cause high mortality; thus, decreasing this mortality is a key therapeutic objective. In order to successfully overcome antimicrobial resistance, a wide variety of therapeutic combinations have been considered as first-line treatments (Table 1) [129]. 
Table 1. Effective Antibiotic Therapies against A. Baumannii according to Therapeutic Groups and Isolated Strains in Specific Clinical Scenarios.

\begin{tabular}{|c|c|c|}
\hline & & Effective Antibiotic Therapy \\
\hline \multirow{3}{*}{$\begin{array}{l}\text { Isolated strains in specific clinical } \\
\text { scenarios }\end{array}$} & $\begin{array}{l}\text { Carbapenem- and } \\
\text { sulbactam-resistant strains. }\end{array}$ & $\begin{array}{l}\text { Doxicycline or minocycline, which in turn } \\
\text { is more effective [130-132] }\end{array}$ \\
\hline & Carbapenem-resistant strains. & TMP-SMX [133] \\
\hline & MDR strains in the ICU. & Tigecycline $[134,135]$. \\
\hline \multirow{4}{*}{ Therapeutic groups } & $\begin{array}{l}\text { Synergistic therapeutic } \\
\text { combinations with } \beta \text {-lactamase } \\
\text { inhibitor sulbactam. }\end{array}$ & $\begin{array}{c}\text { Sulbactam/cefepime, } \\
\text { sulbactam/meropenem, } \\
\text { sulbactam/amikacin, sulbactam/rifampin, } \\
\text { sulbactam/ticarcillin-clavulanate, } \\
\text { sulbactam/ampicillin, sulbactam/colistin } \\
\text { [136], and sulbactam/cefoperazone } \\
\text { [137,138]. }\end{array}$ \\
\hline & $\begin{array}{c}\text { Synergistic therapeutic } \\
\text { combinations with polymyxin E } \\
\text { (colistin). }\end{array}$ & $\begin{array}{c}\text { Colistin/carbapenem [136,139,140] } \\
\text { colistin/minocycline [139], } \\
\text { colistin/tigecycline [141,142], } \\
\text { colistin/rifampin [119,139,143], } \\
\text { colistin/sulbactam [136], } \\
\text { colistin/daptomycin [144], colistin/fusidic } \\
\text { acid [139,145], and colistin/teicoplanin } \\
\text { [144,146]. }\end{array}$ \\
\hline & Last-line therapeutic scheme. & $\begin{array}{l}\text { Polymyxin E (colistin) in combination } \\
\text { with rifampin or polymyxin B with } \\
\text { tigecycline [119]. }\end{array}$ \\
\hline & $\begin{array}{l}\text { Alternative against increasing } \\
\text { antibiotic resistance. }\end{array}$ & Phage B $\varphi$-C62 [147,148]. \\
\hline
\end{tabular}

While therapeutic possibilities against $A$. baumannii decrease, patient mortality and in-hospital stays increase, particularly due to pneumonia and inadequate antimicrobial treatment. A particular antimicrobial therapeutic scheme against $A$. baumannii bacteremia has not been established: there is a lack of adequate studies. Nevertheless, the usual choice is an active $\beta$-lactam alone or in combination with an aminoglycoside. Treatment involving imipenem has also been reported to be useful $[126,129]$.

Other useful therapeutic schemes include colistin/imipenem, colistin/meropenem, colistin/rifampicin, colistin/tigecycline, colistin/sulbactam, colistin/teicoplanin, and imipenem/sulbactam [126,149,150].

As reported by Murray et al., the agents with the most antimicrobial activity are imipenem/cilastatin, amikacin, ampicillin/sulbactam, colistin, and tetracyclines, but no one agent appears superior to any other [126]. Antimicrobial combination therapies against A. baumannii, including colistin/ rifampicin $[139,143]$, colistin/minocycline [139], colistin/carbapenem [136,139,140], colistin/sulbactam [136], colistin/tigecycline [141,142,151,152], colistin/daptomycin [144], colistin/fusidic acid acid [145,153], and colistin/teicoplanin $[144,146]$, are synergistic in vivo or in vitro against such bacteria [149].

In order to prevent bacterial resistance against these drug combinations, the antimicrobials should not be administered in an inhaled form [154].

\subsection{Carbapenem (Imipenem and Meropenem) and $\beta$-Lactam Inhibitors (Sulbactam)}

Common antimicrobial treatments against $A$. baumannii infections include carbapenems; however, the prevalence of isolates resistant to carbapenems (carbapenem-resistant A. baumannii (CRAB)) is increasing, leading to longer in-hospital stays and a higher mortality rate [155].

Imipenem's mechanism against Gram-negative bacilli relies on its capacity to penetrate through the outer cell envelope and to bind with high affinity to certain penicillin-binding protein (PBP) targets. Imipenem and meropenem have high affinity to PBP1a, PBP1b, PBP2, PBP4, and PBP5 [156]. The resistance to a wide variety of $\beta$-lactamases, a direct consequence of its 6 a-hydroxyethyl side chain and the resistance to hydrolysis by the newer enzymes expressed by TEM-2 and SHV-1, are additional mechanisms responsible for the broad-spectrum activity of imipenem $[157,158]$. 
There are three $\beta$-lactamase inhibitors commonly used in the CRAB infections for their intrinsic activity against $A$. baumannii: sulbactam, tazobactam, and clavulanic acid [108]. Sulbactam, as studies have reported, is the most effective and may represent an alternative treatment option for infections caused by MDR A. baumannii strains [2,108,159].

Several studies have demonstrated sulbactam/ampicillin to be a highly effective combination against pneumonia, blood, and nosocomial infections caused by $A$. baumannii $[160,161]$. In vitro studies have shown that sulbactam enhanced its therapeutic activity when combined with cefepime, imipenem, meropenem, amikacin, rifampin, and ticarcillin-clavulanate $[137,138]$. Temocin et al. mentioned, in addition to the previously listed combinations, the synergistic effect of sulbactam with ampicillin and cefoperazone. Further research into the combination with tigecycline is recommended [137].

\subsection{Tetracyclines (Minocycline and Doxycycline) and Glycylcyclines (Tigecycline)}

Tetracycline therapy is a good option when facing carbapenem- and sulbactam-resistant $A$. baumannii strains [130]. When treating pneumonia, doxycycline/amikacin combination is considered viable; however, it has been suggested it does not improve the results obtained by imipenem monotherapy [162].

Both doxycycline and minocycline are effective against ventilator-associated pneumonia (VAP) caused by MDR A. baumannii strains [130]. It must be noted that ACB complex strains from a U.S. Military Hospital were shown to be more susceptible to minocycline that to other tetracyclines and tigecycline, as documented by Akers et al. [131]. Although Holloway et al. suggest further investigation on doxycycline for the treatment of MDR A. baumannii infections [163], Griffith et al. support the effective use of minocycline in treating MDR A. baumannii infections. One of minocycline's benefits, in contrast to imipenem, colistin, and tigecycline, is that it can be given orally to the patient [132].

Tigecycline is a broad-spectrum drug and was the first drug in the glycylcycline antibiotic class, approved in 2005 by the United States Food and Drug Administration (US-FDA) for clinical use [134]. Although it has high structural similarity to minocycline, molecular changes in its structure guarantee less susceptibility to generating resistance when compared with other tetracycline antibiotics [134]. Tigecycline binds to the 30S ribosome subunit and blocks the transfer RNA input to avoid protein synthesis, limiting bacterial growth. Its activity is effective against Gram-positive and Gram-negative bacteria, and has shown good antimicrobial activity against MDR A. baumannii strains, including those resistant to imipenem, associated with ICU nosocomial infections. Gram-positive bacteria, such as S. aureus, Enterococcus spp, coagulase-negative Staphylococcus, and P. aeruginosa have shown greater susceptibility to tigecycline than Gram-negative bacteria [134,164-166].

Nevertheless, Hakyemez et al. analyzed 56 A. baumannii strains, 59\% from ICU (most commonly isolated in reanimation ICU) and did not identify any A. baumannii strain resistant to tigecycline [135].

\subsection{Polymyxins (Colistin and Polymyxin B) and Therapeutic Combinations (Rifampicin and Teicoplanin)}

Colistin (polymyxin E)-based therapy, which is often used in combination, has been described as a last resort for the treatment of MDR A. baumannii. It should be noted that colistin-resistant $A$. baumannii strains have been reported in various regions $[167,168]$.

Polymyxin E (colistin) and polymyxin B are increasingly being used as the last-line therapeutic option for increasing infections against MDR Gram-negative bacteria such as Pseudomonas aeruginosa, Acinetobacter baumannii, and Klebsiella pneumonia [169]. These antimicrobials have various mechanisms through which they kill bacteria. First, they can induce membrane lysis. An electrostatic interaction is generated, allowing the insertion of a particular polymyxin molecule into the outer membrane of the bacteria. The packing of the adjacent lipid A is weakened, facilitating the formation of destabilized areas through which polymyxin crosses the outer membrane. Finally, the integrity of phospholipid bilayer of the inner membrane is compromised, resulting in lysis and cell death. The second mechanism is a vesicle-vesicle contact pathway, through which polymyxin induces a lipid exchange between the outer and the inner membranes, potentially causing an osmotic imbalance and leading to cell death. 
In the third and last mechanism, polymyxins induce rapid killing of Gram-negative bacteria; these antimicrobials induce hydroxyl radical production, which accumulate excessively and lead to bacterial cell death through oxidative damage to DNA, lipids, and proteins [170-172].

It must be noted that colistin is parenterally administered for its inactive prodrug, while polymyxin $B$ is available for direct parenteral administration, thus providing a quicker effect [173].

Colistin is used against MDR Gram-negative bacteria, particularly A. baumannii, in combination with other drugs, such as colistin-rifampin, colistin-meropenem, colistin-minocycline, colistin-carbapenem, colistin-sulbactam, and colistin-teicoplanin [139,174,175]. Evidence shows that Acinetobacter isolates were previously susceptible to colistin, however, now they are characterized by resistance and, in some cases, dependence on this antimicrobial. Patients suffering from A. baumannii infections dependent to colistin are associated with a high rate of failure in treatment [176,177].

Dubrovskaya et al. suggest further research regarding the nephrotoxic effect associated with polymyxin B. Taking this into account, healthcare providers may limit the toxic effects of therapeutic combination in a patient with a MDR infection [178].

However, in vitro studies have demonstrated the effective use of polymyxin B in combination with certain antibiotics to treat multidrug-resistant infections caused by $A$. baumannii. It has been successful when used in combination with carbapenems (doripenem, meropenem or imipenem), rifampicin, and tigecycline [179-181]. As tigecycline also has microbiological activity against multidrug-resistant isolates, its combination with polymyxin B against A. baumannii infections is common [179].

\subsection{Trimethoprim (TMP)-Sulfamethoxazole (SMX)}

In vitro studies have demonstrated the efficacy of TMP-SMX combination against CRAB infections [133]. Reducing the production of tetrahydrofolate (FAH4), essential to cellular growth and survival, by inhibiting the activity of reductases that under normal circumstances maintain FAH4 pools, is the characteristic mechanism by which TMP kills bacteria. Its antimicrobial effect is enhanced when used in combination with SMX, as it simultaneously blocks the synthesis of FAH2 [182,183].

\subsection{Bacteriophages, Endolysin (Artilysin)}

Bacteriophages are bacteria-infecting viruses with precise bacteriolytic activity. MDR isolates of A. baumannii, including $\mathrm{CRAB}$, can be targets for such bacteriophages, so they are being considered as a useful alternative to face drug resistance. No deleterious side effects associated with their use have been reported [147,148]. Phage B $\varphi-C 62$ has shown the strongest lytic activity [147]. It must be noted that Schooley et al. reported the reversal of a diabetic patient's downward clinical trajectory caused by necrotizing pancreatitis complicated by MDR $A$. baumannii infection after the administration of these bacteriophages intravenously [184]. However, this therapy's high cost and low experimental evidence limit its usage.

Endolysins are soluble enzymes that are produced and released by double-stranded DNA phages at the end of their replication cycle to degrade the peptidoglycan of the bacterial host, thus leading to cell lysis and the release of progeny virions. A second lysis factor is involved in this process, known as holing [185]. Its fast action, high specificity, efficacy, low toxicity, and low probability to produce resistance make these endolysins a potential efficient treatment for MDR bacterial infections [186]. The mechanism involved is similar to that of a peptoglycan hydrolase. The endolysins are more effective against Gram-positive bacteria. On the other hand, Gram-negative bacteria are naturally protected from endolysins by their outer membrane, which protects the target of endolysins: the peptoglycan. In order for endolysins to be effective against Gram-negative bacteria, they have to be genetically modified into "artilysins". Huang et al. expect that phage-encoded endolysins could become very useful antibacterial agents against pathogens. Specifically, endolysin gene plyB1, which codes for endolysin from the Abp1 phage, has potential as an antibiotic against MDR A. baumannii [187]. 


\section{Conclusions}

A. baumannii has developed multiple antibiotic resistance mechanisms, increasing the harmful consequences of its pathogenic potential and representing an important challenge for patients and healthcare providers. Clinicians have to take into account all documented risk factors and the experimental synergistic activity of different antimicrobials in order to achieve a more successful treatment for patients with MDR A. baumannii infections. Effectiveness of treatment relies mostly on accurate antimicrobial combinations with sulbactam or polymyxin E (colistin). On the other hand, monotherapy has been described as successful against particular $A$. baumannii strains in certain clinical scenarios. Although the use of $\beta$-lactam alone or in combination with an aminoglycoside is common, increasing rates of resistant strains demand the use of an effective $\beta$-lactamase inhibitor, such as sulbactam. Nevertheless, sulbactam-resistant strains have been reported. Additionally, strains resistant and dependent to polymyxin use could exceed its efficacy in antimicrobial combinations. Therefore, the use of tigecycline, alone or in combination, or Phage $\mathrm{B} \varphi-\mathrm{C} 62$ remain as the antimicrobials with most potential against MDR A. baumannii infections. The WHO included CRAB (carbapenem-resistant A. baumannii) in the "critical group" of bacteria that represent the greatest threat to human health and recommended further research to face its clinical impact; however, in addition to investment in new therapeutic alternatives, efforts must be oriented towards limiting the indiscriminate hospital use of broad-spectrum antibiotics. Antimicrobial resistance will become a major concern in years to come, and its expected clinical impact will only be limited if multidisciplinary teams gather around the world to develop innovative solutions not only at a molecular level, but also at an institutional one.

Author Contributions: R.V.-L. contributed to the conception and design of this project, general supervision of the research group and gave final approval of this manuscript. S.G.S.-G. contributed substantially to drafting of the manuscript, J.J.J.V.-W. was involved in drafting of the manuscript, J.A.A.V. was involved in drafting of the manuscript, L.A.P.A. was involved in drafting of the manuscript, A.R.R. was involved in drafting of the manuscript, M.M.Á. was involved in drafting of the manuscript, E.N.V.L. was involved in drafting of the manuscript, G.F.-K. was involved in drafting of the manuscript, D.A.Á.-H. was involved in drafting of the manuscript, V.M.G. was involved in drafting of the manuscript, J.E.J.B. was involved in drafting of the manuscript, J.M.F. was involved in drafting of the manuscript, J.A.G.B. was involved in drafting of the manuscript, T.B.F. was involved in drafting of the manuscript. All authors have read and agreed to the published version of the manuscript.

Funding: This work is part of the project number 201638-CSNBIAVALR170605171 funded by CICSA, FCS Universidad Anáhuac México, Campus Norte.

Acknowledgments: The authors thank A.I. for his support and comments on this research.

Conflicts of Interest: The authors have no competing interests.

\section{References}

1. Beijerinck, M. Pigmenten als oxydatieproducten door bacterien gevormd. Versl. K. Akad. Wetensch. Amst. 1911, 19, 1092-1103.

2. Peleg, A.Y.; Seifert, H.; Paterson, D.L. Acinetobacter baumannii: Emergence of a successful pathogen. Clin. Microbiol. Rev. 2008, 21, 538-582. [CrossRef]

3. Brisou, J.; Prevot, A.R. Studies on bacterial taxonomy. X. The revision of species under Acromobacter group. Ann. Inst. Pasteur. 1954, 86, 722-728.

4. Baumann, P.; Doudoroff, M.; Stanier, R.Y. A study of the Moraxella group. II. Oxidative-negative species (genus Acinetobacter). J. Bacteriol. 1968, 95, 1520-1541. [CrossRef]

5. Lessel, E.F. International Committee on Nomenclature of Bacteria Subcommittee on the Taxonomy of Moraxella and Allied Bacteria: Minutes of the Meeting, 11 August 1970. Room Constitution C, Maria-Isabel Hotel, Mexico City, Mexico. Int. J. Syst. Bacteriol. 1971, 21, 213-214. [CrossRef]

6. Wong, D.; Nielsen, T.B.; Bonomo, R.A.; Pantapalangkoor, P.; Luna, B.; Spellberg, B. Clinical and pathophysiological overview of Acinetobacter infections: A century of challenges. Clin. Microbiol. Rev. 2017, 30, 409-447. [CrossRef] [PubMed] 
7. Chusri, S.; Chongsuvivatwong, V.; Rivera, J.I.; Silpapojakul, K.; Singkhamanan, K.; McNeil, E.; Doi, Y. Clinical outcomes of hospital-acquired infection with Acinetobacter nosocomialis and Acinetobacter pittii. Antimicrob. Agents Chemother. 2014, 58, 4172-4179. [CrossRef] [PubMed]

8. Chang, W.N.; Lu, C.H.; Huang, C.R.; Chuang, Y.C. Community-acquired Acinetobacter meningitis in adults. Infection 2000, 28, 395-397. [CrossRef] [PubMed]

9. Touchon, M.; Cury, J.; Yoon, E.J.; Krizova, L.; Cerqueira, G.C.; Murphy, C.; Feldgarden, M.; Wortman, J.; Clermont, D.; Lambert, T.; et al. The genomic diversification of the whole Acinetobacter genus: Origins, mechanisms, and consequences. Genome Biol. Evol. 2014, 6, 2866-2882. [CrossRef]

10. Kumar, S.; Stecher, G.; Suleski, M.; Hedges, S.B. TimeTree: A Resource for Timelines, Timetrees, and Divergence Times. Mol. Biol. Evol. 2017, 34, 1812-1819. [CrossRef]

11. Tjernberg, I. Antimicrobial susceptibility of Acinetobacter strains identified by DNA-DNA hybridization. APMIS 1990, 98, 320-326. [CrossRef] [PubMed]

12. Towner, K.J. Acinetobacter: An old friend, but a new enemy. J. Hosp. Infect. 2009, 73, 355-363. [CrossRef]

13. Chuang, Y.-C.; Sheng, W.-H.; Li, S.-Y.; Lin, Y.-C.; Wang, J.-T.; Chen, Y.-C.; Chang, S.-C. Influence of Genospecies of Acinetobacter baumannii Complex on Clinical Outcomes of Patients with Acinetobacter Bacteremia. Clin. Infect. Dis. 2011, 52, 352-360. [CrossRef] [PubMed]

14. Weinstein, R.A.; Gaynes, R.; Edwards, J.R. Overview of Nosocomial Infections Caused by Gram-Negative Bacilli. Clin. Infect. Dis. 2005, 41, 848-854. [CrossRef] [PubMed]

15. Blossom, D.B.; Srinivasan, A. Drug-Resistant Acinetobacter baumannii-calcoaceticus Complex. Infect. Dis. Clin. Pract. 2008, 16, 1-3. [CrossRef]

16. Boucher, H.W.; Talbot, G.H.; Bradley, J.S.; Edwards, J.E.; Gilbert, D.; Rice, L.B.; Scheld, M.; Spellberg, B.; Bartlett, J. Bad Bugs, No Drugs: No ESKAPE! An Update from the Infectious Diseases Society of America. Clin. Infect. Dis. 2009, 48, 1-12. [CrossRef] [PubMed]

17. Cai, Y.; Chai, D.; Wang, R.; Liang, B.; Bai, N. Colistin resistance of Acinetobacter baumannii: Clinical reports, mechanisms and antimicrobial strategies. J. Antimicrob. Chemother. 2012, 67, 1607-1615. [CrossRef]

18. The Antibiotic Alarm. 2013. Available online: https://www.nature.com/news/polopoly_fs/1.12579!/menu/ main/topColumns/topLeftColumn/pdf/495141a.pdf (accessed on 20 April 2020).

19. Read, A.F.; Woods, R.J. Antibiotic resistance management. Evol. Med. Public Heal. 2014, 2014, 147. [CrossRef]

20. Luyt, C.E.; Bréchot, N.; Trouillet, J.L.; Chastre, J. Antibiotic stewardship in the intensive care unit. Crit. Care 2014, 18. [CrossRef]

21. CDC CARBAPENEM-RESISTANT ACINETOBACTER. Available online: https://www.cdc.gov/drugresistance/ pdf/threats-report/acinetobacter-508.pdf (accessed on 20 April 2020).

22. Bartlett, J.G.; Gilbert, D.N.; Spellberg, B. Seven Ways to Preserve the Miracle of Antibiotics. Clin. Infect. Dis. 2013, 56, 1445-1450. [CrossRef]

23. Chen, L.-K.; Kuo, S.-C.; Chang, K.-C.; Cheng, C.-C.; Yu, P.-Y.; Chang, C.-H.; Chen, T.-Y.; Tseng, C.-C. Clinical Antibiotic-resistant Acinetobacter baumannii Strains with Higher Susceptibility to Environmental Phages than Antibiotic-sensitive Strains. Sci. Rep. 2017, 7, 6319. [CrossRef] [PubMed]

24. Gordon, N.C.; Wareham, D.W. Multidrug-resistant Acinetobacter baumannii: Mechanisms of virulence and resistance. Int. J. Antimicrob. Agents 2010, 35, 219-226. [CrossRef] [PubMed]

25. WHO. WHO Global Strategy for Containment of Antimicrobial Resistance. Available online: https://apps.who. int/iris/bitstream/handle/10665/66860/WHO_CDS_CSR_DRS_2001.2.pdf?sequence=1\&isAllowed=y (accessed on 20 April 2020).

26. Lee, S.-O.; Kim, N.J.; Choi, S.-H.; Hyong Kim, T.; Chung, J.-W.; Woo, J.-H.; Ryu, J.; Kim, Y.S. Risk factors for acquisition of imipenem-resistant Acinetobacter baumannii: A case-control study. Antimicrob. Agents Chemother. 2004, 48, 224-228. [CrossRef]

27. Lemos, E.V.; de la Hoz, F.P.; Einarson, T.R.; McGhan, W.F.; Quevedo, E.; Castañeda, C.; Kawai, K. Carbapenem resistance and mortality in patients with Acinetobacter baumannii infection: Systematic review and meta-analysis. Clin. Microbiol. Infect. 2014, 20, 416-423. [CrossRef] [PubMed]

28. Grupper, M.; Sprecher, H.; Mashiach, T.; Finkelstein, R. Attributable Mortality of Nosocomial Acinetobacter Bacteremia. Infect. Control Hosp. Epidemiol. 2007, 28, 293-298. [CrossRef]

29. Sunenshine, R.H.; Wright, M.-O.; Maragakis, L.L.; Harris, A.D.; Song, X.; Hebden, J.; Cosgrove, S.E.; Anderson, A.; Carnell, J.; Jernigan, D.B.; et al. Multidrug-resistant Acinetobacter Infection Mortality Rate and Length of Hospitalization. Emerg. Infect. Dis. 2007, 13, 97-103. [CrossRef] 
30. Kim, Y.J.; Kim, S., II; Hong, K.-W.; Kim, Y.R.; Park, Y.J.; Kang, M.-W. Risk factors for mortality in patients with carbapenem-resistant Acinetobacter baumannii bacteremia: Impact of appropriate antimicrobial therapy. J. Korean Med. Sci. 2012, 27, 471-475. [CrossRef]

31. Munoz-Price, L.S.; Zembower, T.; Penugonda, S.; Schreckenberger, P.; Lavin, M.A.; Welbel, S.; Vais, D.; Baig, M.; Mohapatra, S.; Quinn, J.P.; et al. Clinical Outcomes of Carbapenem-Resistant Acinetobacter baumannii Bloodstream Infections: Study of a 2-State Monoclonal Outbreak. Infect. Control Hosp. Epidemiol. 2010, 31, 1057-1062. [CrossRef]

32. Choi, J.Y.; Park, Y.S.; Kim, C.O.; Park, Y.S.; Yoon, H.J.; Shin, S.Y.; Kim, Y.-A.; Song, Y.G.; Yong, D.; Lee, K.; et al. Mortality risk factors of Acinetobacter baumannii bacteraemia. Intern. Med. J. 2005, 35, 599-603. [CrossRef]

33. Chen, H.P.; Chen, T.L.; Lai, C.H.; Fung, C.P.; Wong, W.W.; Yu, K.W.; Liu, C.Y. Predictors of mortality in Acinetobacter baumannii bacteremia. J. Microbiol. Immunol. Infect. 2005, 38, 127-136.

34. Harding, C.M.; Hennon, S.W.; Feldman, M.F. Uncovering the mechanisms of Acinetobacter baumannii virulence. Nat. Rev. Microbiol. 2018, 16, 91-102. [CrossRef] [PubMed]

35. Giammanco, A.; Calà, C.; Fasciana, T.; Dowzicky, M.J. Global Assessment of the Activity of Tigecycline against Multidrug-Resistant Gram-Negative Pathogens between 2004 and 2014 as Part of the Tigecycline Evaluation and Surveillance Trial. mSphere 2017, 2. [CrossRef] [PubMed]

36. Rolain, J.-M.; Diene, S.M.; Kempf, M.; Gimenez, G.; Robert, C.; Raoult, D. Real-Time Sequencing To Decipher the Molecular Mechanism of Resistance of a Clinical Pan-Drug-Resistant Acinetobacter baumannii Isolate from Marseille, France. Antimicrob. Agents Chemother. 2013, 57, 592-596. [CrossRef] [PubMed]

37. Magill, S.S.; Edwards, J.R.; Bamberg, W.; Beldavs, Z.G.; Dumyati, G.; Kainer, M.A.; Lynfield, R.; Maloney, M.; McAllister-Hollod, L.; Nadle, J.; et al. Multistate Point-Prevalence Survey of Health Care-Associated Infections. N. Engl. J. Med. 2014, 370, 1198-1208. [CrossRef]

38. Lob, S.H.; Hoban, D.J.; Sahm, D.F.; Badal, R.E. Regional differences and trends in antimicrobial susceptibility of Acinetobacter baumannii. Int. J. Antimicrob. Agents 2016, 47, 317-323. [CrossRef]

39. WHO. Global Priority List of Antibiotic-Resistant Bacteria to Guide Research, Discovery, and Development of New Antibiotics. Available online: https:/www.who.int/medicines/publications/global-priority-listantibiotic-resistant-bacteria/en/ (accessed on 20 April 2020).

40. Vallenet, D.; Nordmann, P.; Barbe, V.; Poirel, L.; Mangenot, S.; Bataille, E.; Dossat, C.; Gas, S.; Kreimeyer, A.; Lenoble, P.; et al. Comparative Analysis of Acinetobacters: Three Genomes for Three Lifestyles. PLoS ONE 2008, 3, e1805. [CrossRef]

41. Luke, N.R.; Sauberan, S.L.; Russo, T.A.; Beanan, J.M.; Olson, R.; Loehfelm, T.W.; Cox, A.D.; Michael, F.S.; Vinogradov, E.V.; Campagnari, A.A. Identification and Characterization of a Glycosyltransferase Involved in Acinetobacter baumannii Lipopolysaccharide Core Biosynthesis. Infect. Immun. 2010, 78, 2017-2023. [CrossRef]

42. Powers, M.J.; Herrera, C.M.; Tucker, A.T.; Davies, B.W.; Trent, M.S. Isolation of Lipid Cell Envelope Components from Acinetobacter baumannii. In Acinetobacter baumannii; Humana Press: New York, NY, USA, 2019; Volume 1946, pp. 233-252.

43. Bartholomew, T.L.; Kidd, T.J.; Sá Pessoa, J.; Conde Álvarez, R.; Bengoechea, J.A. 2-Hydroxylation of Acinetobacter baumannii Lipid A Contributes to Virulence. Infect. Immun. 2019, 87, e00066-19. [CrossRef]

44. Boll, J.M.; Tucker, A.T.; Klein, D.R.; Beltran, A.M.; Brodbelt, J.S.; Davies, B.W.; Trent, M.S. Reinforcing Lipid A Acylation on the Cell Surface of Acinetobacter baumannii Promotes Cationic Antimicrobial Peptide Resistance and Desiccation Survival. MBio 2015, 6, e00478-15. [CrossRef]

45. Chen, H.D.; Groisman, E.A. The Biology of the PmrA/PmrB Two-Component System: The Major Regulator of Lipopolysaccharide Modifications. Annu. Rev. Microbiol. 2013, 67, 83-112. [CrossRef] [PubMed]

46. Knapp, S.; Wieland, C.W.; Florquin, S.; Pantophlet, R.; Dijkshoorn, L.; Tshimbalanga, N.; Akira, S.; van der Poll, T. Differential Roles of CD14 and Toll-like Receptors 4and 2 in Murine Acinetobacter Pneumonia. Am. J. Respir. Crit. Care Med. 2006, 173, 122-129. [CrossRef] [PubMed]

47. Erridge, C.; Moncayo-Nieto, O.L.; Morgan, R.; Young, M.; Poxton, I.R. Acinetobacter baumannii lipopolysaccharides are potent stimulators of human monocyte activation via Toll-like receptor 4 signalling. J. Med. Microbiol. 2007, 56, 165-171. [CrossRef] [PubMed]

48. March, C.; Regueiro, V.; Llobet, E.; Moranta, D.; Morey, P.; Garmendia, J.; Bengoechea, J.A. Dissection of Host Cell Signal Transduction during Acinetobacter baumannii-Triggered Inflammatory Response. PLoS ONE 2010, 5, e10033. [CrossRef] [PubMed] 
49. Jacobs, A.C.; Hood, I.; Boyd, K.L.; Olson, P.D.; Morrison, J.M.; Carson, S.; Sayood, K.; Iwen, P.C.; Skaar, E.P.; Dunman, P.M. Inactivation of phospholipase D diminishes Acinetobacter baumannii pathogenesis. Infect. Immun. 2010, 78, 1952-1962. [CrossRef] [PubMed]

50. Camarena, L.; Bruno, V.; Euskirchen, G.; Poggio, S.; Snyder, M. Molecular Mechanisms of Ethanol-Induced Pathogenesis Revealed by RNA-Sequencing. PLoS Pathog. 2010, 6, e1000834. [CrossRef] [PubMed]

51. Russo, T.A.; Luke, N.R.; Beanan, J.M.; Olson, R.; Sauberan, S.L.; MacDonald, U.; Schultz, L.W.; Umland, T.C.; Campagnari, A.A. The K1 Capsular Polysaccharide of Acinetobacter baumannii Strain 307-0294 Is a Major Virulence Factor. Infect. Immun. 2010, 78, 3993-4000. [CrossRef]

52. Kwon, S.-O.; Gho, Y.S.; Lee, J.C.; Kim, S. Il Proteome analysis of outer membrane vesicles from a clinical Acinetobacter baumannii isolate. FEMS Microbiol. Lett. 2009, 297, 150-156. [CrossRef]

53. Choi, C.H.; Hyun, S.H.; Lee, J.Y.; Lee, J.S.; Lee, Y.S.; Kim, S.A.; Chae, J.-P.; Yoo, S.M.; Lee, J.C. Acinetobacter baumannii outer membrane protein A targets the nucleus and induces cytotoxicity. Cell. Microbiol. 2007, 0, 309-319. [CrossRef]

54. Choi, C.H.; Lee, E.Y.; Lee, Y.C.; Park, T.I.; Kim, H.J.; Hyun, S.H.; Kim, S.A.; Lee, S.-K.; Lee, J.C. Outer membrane protein 38 of Acinetobacter baumannii localizes to the mitochondria and induces apoptosis of epithelial cells. Cell. Microbiol. 2005, 7, 1127-1138. [CrossRef]

55. Choi, C.H.; Lee, J.S.; Lee, Y.C.; Park, T.I.; Lee, J.C. Acinetobacter baumannii invades epithelial cells and outer membrane protein A mediates interactions with epithelial cells. BMC Microbiol. 2008, 8, 216. [CrossRef]

56. Lee, J.C.; Oh, J.Y.; Kim, K.S.; Jeong, Y.W.; Park, J.C.; Cho, J.W. Apoptotic cell death induced by Acinetobacter baumannii in epithelial cells through caspase-3 activation. APMIS 2001, 109, 679-684. [CrossRef]

57. Lee, J.S.; Lee, J.C.; Lee, C.-M.; Jung, I.D.; Jeong, Y.-I.; Seong, E.-Y.; Chung, H.-Y.; Park, Y.-M. Outer membrane protein A of Acinetobacter baumannii induces differentiation of CD4+ T cells toward a Th1 polarizing phenotype through the activation of dendritic cells. Biochem. Pharmacol. 2007, 74, 86-97. [CrossRef] [PubMed]

58. Kim, S.A.; Yoo, S.M.; Hyun, S.H.; Choi, C.H.; Yang, S.Y.; Kim, H.J.; Jang, B.C.; Suh, S., II; Lee, J.C. Global gene expression patterns and induction of innate immune response in human laryngeal epithelial cells in response to Acinetobacter baumannii outer membrane protein A. FEMS Immunol. Med. Microbiol. 2008, 54, 45-52. [CrossRef] [PubMed]

59. Choi, C.H.; Hyun, S.H.; Kim, J.; Lee, Y.C.; Seol, S.Y.; Cho, D.T.; Lee, J.C. Nuclear translocation and DNAse I-like enzymatic activity of Acinetobacter baumannii outer membrane protein A. FEMS Microbiol. Lett. 2008, 288, 62-67. [CrossRef] [PubMed]

60. Kim, S.W.; Choi, C.H.; Moon, D.C.; Jin, J.S.; Lee, J.H.; Shin, J.-H.; Kim, J.M.; Lee, Y.C.; Seol, S.Y.; Cho, D.T.; et al. Serum resistance of Acinetobacter baumannii through the binding of factor $\mathrm{H}$ to outer membrane proteins. FEMS Microbiol. Lett. 2009, 301, 224-231. [CrossRef] [PubMed]

61. Gaddy, J.A.; Tomaras, A.P.; Actis, L.A. The Acinetobacter baumannii 19606 OmpA Protein Plays a Role in Biofilm Formation on Abiotic Surfaces and in the Interaction of This Pathogen with Eukaryotic Cells. Infect. Immun. 2009, 77, 3150-3160. [CrossRef] [PubMed]

62. Lee, H.-W.; Koh, Y.M.; Kim, J.; Lee, J.-C.; Lee, Y.-C.; Seol, S.-Y.; Cho, D.-T.; Kim, J. Capacity of multidrug-resistant clinical isolates of Acinetobacter baumannii to form biofilm and adhere to epithelial cell surfaces. Clin. Microbiol. Infect. 2008, 14, 49-54. [CrossRef]

63. Cevahir, N.; Demir, M.; Kaleli, I.; Gurbuz, M.; Tikvesli, S. Evaluation of biofilm production, gelatinase activity, and mannose-resistant hemagglutination in Acinetobacter baumannii strains. J. Microbiol. Immunol. Infect. 2008, 41, 513-518.

64. Vidal, R.; Dominguez, M.; Urrutia, H.; Bello, H.; Gonzalez, G.; Garcia, A.; Zemelman, R. Biofilm formation by Acinetobacter baumannii. Microbios 1996, 86, 49-58.

65. Tomaras, A.P.; Dorsey, C.W.; Edelmann, R.E.; Actis, L.A. Attachment to and biofilm formation on abiotic surfaces by Acinetobacter baumannii: Involvement of a novel chaperone-usher pili assembly system. Microbiology 2003, 149, 3473-3484. [CrossRef]

66. Jawad, A.; Heritage, J.; Snelling, A.M.; Gascoyne-Binzi, D.M.; Hawkey, P.M. Influence of relative humidity and suspending menstrua on survival of Acinetobacter spp. on dry surfaces. J. Clin. Microbiol. 1996, 34, 2881-2887. [CrossRef]

67. Giannouli, M.; Antunes, L.C.; Marchetti, V.; Triassi, M.; Visca, P.; Zarrilli, R. Virulence-related traits of epidemic Acinetobacter baumannii strains belonging to the international clonal lineages I-III and to the emerging genotypes ST25 and ST78. BMC Infect. Dis. 2013, 13, 282. [CrossRef] 
68. Antunes, L.C.S.; Imperi, F.; Carattoli, A.; Visca, P. Deciphering the Multifactorial Nature of Acinetobacter baumannii Pathogenicity. PLoS ONE 2011, 6, e22674. [CrossRef]

69. Loehfelm, T.W.; Luke, N.R.; Campagnari, A.A. Identification and Characterization of an Acinetobacter baumannii Biofilm-Associated Protein. J. Bacteriol. 2008, 190, 1036-1044. [CrossRef]

70. Choi, A.H.K.; Slamti, L.; Avci, F.Y.; Pier, G.B.; Maira-Litrán, T. The pgaABCD locus of Acinetobacter baumannii encodes the production of poly-beta-1-6-N-acetylglucosamine, which is critical for biofilm formation. J. Bacteriol. 2009, 191, 5953-5963. [CrossRef] [PubMed]

71. Davies, D.G.; Parsek, M.R.; Pearson, J.P.; Iglewski, B.H.; Costerton, J.W.; Greenberg, E.P. The involvement of cell-to-cell signals in the development of a bacterial biofilm. Science 1998, 280, 295-298. [CrossRef] [PubMed]

72. Rumbaugh, K.P. Convergence of hormones and autoinducers at the host/pathogen interface. Anal. Bioanal. Chem. 2007, 387, 425-435. [CrossRef]

73. Braun, V. Iron uptake mechanisms and their regulation in pathogenic bacteria. Int. J. Med. Microbiol. 2001, 291, 67-79. [CrossRef] [PubMed]

74. Actis, L.A.; Tolmasky, M.E.; Crosa, L.M.; Crosa, J.H. Effect of iron-limiting conditions on growth of clinical isolates of Acinetobacter baumannii. J. Clin. Microbiol. 1993, 31, 2812-2815. [CrossRef]

75. Woodford, N.; Turton, J.F.; Livermore, D.M. Multiresistant Gram-negative bacteria: The role of high-risk clones in the dissemination of antibiotic resistance. FEMS Microbiol. Rev. 2011, 35, 736-755. [CrossRef]

76. Landman, D.; Kelly, P.; Backer, M.; Babu, E.; Shah, N.; Bratu, S.; Quale, J. Antimicrobial activity of a novel aminoglycoside, ACHN-490, against Acinetobacter baumannii and Pseudomonas aeruginosa from New York City. J. Antimicrob. Chemother. 2011, 66, 332-334. [CrossRef] [PubMed]

77. Shaw, K.J.; Rather, P.N.; Hare, R.S.; Miller, G.H. Molecular genetics of aminoglycoside resistance genes and familial relationships of the aminoglycoside-modifying enzymes. Microbiol. Rev. 1993, 57, 138-163. [CrossRef] [PubMed]

78. Akers, K.S.; Chaney, C.; Barsoumian, A.; Beckius, M.; Zera, W.; Yu, X.; Guymon, C.; Keen, E.F.; Robinson, B.J.; Mende, K.; et al. Aminoglycoside resistance and susceptibility testing errors in Acinetobacter baumannii-calcoaceticus complex. J. Clin. Microbiol. 2010, 48, 1132-1138. [CrossRef] [PubMed]

79. Liou, G.F.; Yoshizawa, S.; Courvalin, P.; Galimand, M. Aminoglycoside Resistance by ArmA-mediated Ribosomal 16S Methylation in Human Bacterial Pathogens. J. Mol. Biol. 2006, 359, 358-364. [CrossRef] [PubMed]

80. Yu, Y.; Zhou, H.; Yang, Q.; Chen, Y.; Li, L. Widespread occurrence of aminoglycoside resistance due to ArmA methylase in imipenem-resistant Acinetobacter baumannii isolates in China. J. Antimicrob. Chemother. 2007, 60, 454-455. [CrossRef] [PubMed]

81. Doi, Y.; Adams, J.M.; Yamane, K.; Paterson, D.L. Identification of 16S rRNA methylase-producing Acinetobacter baumannii clinical strains in North America. Antimicrob. Agents Chemother. 2007, 51, 4209-4210. [CrossRef] [PubMed]

82. Cho, Y.J.; Moon, D.C.; Jin, J.S.; Choi, C.H.; Lee, Y.C.; Lee, J.C. Genetic basis of resistance to aminoglycosides in Acinetobacter spp. and spread of armA in Acinetobacter baumannii sequence group 1 in Korean hospitals. Diagn. Microbiol. Infect. Dis. 2009, 64, 185-190. [CrossRef]

83. Jeon, J.H.; Lee, J.H.; Lee, J.J.; Park, K.S.; Karim, A.M.; Lee, C.-R.; Jeong, B.C.; Lee, S.H. Structural basis for carbapenem-hydrolyzing mechanisms of carbapenemases conferring antibiotic resistance. Int. J. Mol. Sci. 2015, 16, 9654-9692. [CrossRef]

84. Rumbo, C.; Gato, E.; López, M.; Ruiz de Alegría, C.; Fernández-Cuenca, F.; Martínez-Martínez, L.; Vila, J.; Pachón, J.; Cisneros, J.M.; Rodríguez-Baño, J.; et al. Contribution of efflux pumps, porins, and $\beta$-lactamases to multidrug resistance in clinical isolates of Acinetobacter baumannii. Antimicrob. Agents Chemother. 2013, 57, 5247-5257. [CrossRef]

85. Héritier, C.; Poirel, L.; Lambert, T.; Nordmann, P. Contribution of acquired carbapenem-hydrolyzing oxacillinases to carbapenem resistance in Acinetobacter baumannii. Antimicrob. Agents Chemother. 2005, 49, 3198-3202. [CrossRef]

86. Adams-Haduch, J.M.; Paterson, D.L.; Sidjabat, H.E.; Pasculle, A.W.; Potoski, B.A.; Muto, C.A.; Harrison, L.H.; Doi, Y. Genetic basis of multidrug resistance in Acinetobacter baumannii clinical isolates at a tertiary medical center in Pennsylvania. Antimicrob. Agents Chemother. 2008, 52, 3837-3843. [CrossRef] [PubMed] 
87. Perez, F.; Hujer, A.M.; Hujer, K.M.; Decker, B.K.; Rather, P.N.; Bonomo, R.A. Global Challenge of Multidrug-Resistant Acinetobacter baumannii. Antimicrob. Agents Chemother. 2007, 51,3471-3484. [CrossRef] [PubMed]

88. Zarrilli, R.; Crispino, M.; Bagattini, M.; Barretta, E.; Di Popolo, A.; Triassi, M.; Villari, P. Molecular epidemiology of sequential outbreaks of Acinetobacter baumannii in an intensive care unit shows the emergence of carbapenem resistance. J. Clin. Microbiol. 2004, 42, 946-953. [CrossRef] [PubMed]

89. Vila, J.; Navia, M.; Ruiz, J.; Casals, C. Cloning and nucleotide sequence analysis of a gene encoding an OXA-derived beta-lactamase in Acinetobacter baumannii. Antimicrob. Agents Chemother. 1997, 41, 2757-2759. [CrossRef]

90. Poirel, L.; Girlich, D.; Naas, T.; Nordmann, P. OXA-28, an extended-spectrum variant of OXA-10 beta-lactamase from Pseudomonas aeruginosa and its plasmid- and integron-located gene. Antimicrob. Agents Chemother. 2001, 45, 447-453. [CrossRef]

91. Higgins, P.G.; Pérez-Llarena, F.J.; Zander, E.; Fernández, A.; Bou, G.; Seifert, H. OXA-235, a Novel Class D $\beta$-Lactamase Involved in Resistance to Carbapenems in Acinetobacter baumannii. Antimicrob. Agents Chemother. 2013, 57, 2121-2126. [CrossRef]

92. Mugnier, P.D.; Poirel, L.; Naas, T.; Nordmann, P. Worldwide Dissemination of the bla OXA-23 Carbapenemase Gene of Acinetobacter baumannii 1. Emerg. Infect. Dis. 2009, 16, 35-40. [CrossRef]

93. Bou, G.; Oliver, A.; Martínez-Beltrán, J. OXA-24, a Novel Class D $\beta$-Lactamase with Carbapenemase Activity in an Acinetobacter baumanniiClinical Strain. Antimicrob. Agents Chemother. 2000, 44, 1556-1561. [CrossRef]

94. Figueiredo, S.; Poirel, L.; Papa, A.; Koulourida, V.; Nordmann, P. Overexpression of the naturally occurring blaOXA-51 gene in Acinetobacter baumannii mediated by novel insertion sequence ISAba9. Antimicrob. Agents Chemother. 2009, 53, 4045-4047. [CrossRef]

95. Turton, J.F.; Ward, M.E.; Woodford, N.; Kaufmann, M.E.; Pike, R.; Livermore, D.M.; Pitt, T.L. The role of ISAba1 in expression of OXA carbapenemase genes in Acinetobacter baumannii. FEMS Microbiol. Lett. 2006, 258, 72-77. [CrossRef]

96. Viehman, J.A.; Nguyen, M.H.; Doi, Y. Treatment Options for Carbapenem-Resistant and Extensively Drug-Resistant Acinetobacter baumannii Infections. Drugs 2014, 74, 1315-1333. [CrossRef]

97. Chen, Y.; Zhou, Z.; Jiang, Y.; Yu, Y. Emergence of NDM-1-producing Acinetobacter baumannii in China. J. Antimicrob. Chemother. 2011, 66, 1255-1259. [CrossRef]

98. Tsakris, A.; Ikonomidis, A.; Pournaras, S.; Tzouvelekis, L.S.; Sofianou, D.; Legakis, N.J.; Maniatis, A.N. VIM-1 metallo-beta-lactamase in Acinetobacter baumannii. Emerg. Infect. Dis. 2006, 12, 981-983. [CrossRef] [PubMed]

99. Lee, K.; Yum, J.H.; Yong, D.; Lee, H.M.; Kim, H.D.; Docquier, J.-D.; Rossolini, G.M.; Chong, Y. Novel acquired metallo-beta-lactamase gene, bla(SIM-1), in a class 1 integron from Acinetobacter baumannii clinical isolates from Korea. Antimicrob. Agents Chemother. 2005, 49, 4485-4491. [CrossRef] [PubMed]

100. Fernández-Cuenca, F.; Martínez-Martínez, L.; Conejo, M.C.; Ayala, J.A.; Perea, E.J.; Pascual, A. Relationship between beta-lactamase production, outer membrane protein and penicillin-binding protein profiles on the activity of carbapenems against clinical isolates of Acinetobacter baumannii. J. Antimicrob. Chemother. 2003, 51, 565-574. [CrossRef] [PubMed]

101. Coyne, S.; Rosenfeld, N.; Lambert, T.; Courvalin, P.; Perichon, B. Overexpression of Resistance-Nodulation-Cell Division Pump AdeFGH Confers Multidrug Resistance in Acinetobacter baumannii. Antimicrob. Agents Chemother. 2010, 54, 4389-4393. [CrossRef] [PubMed]

102. Hujer, K.M.; Hamza, N.S.; Hujer, A.M.; Perez, F.; Helfand, M.S.; Bethel, C.R.; Thomson, J.M.; Anderson, V.E.; Barlow, M.; Rice, L.B.; et al. Identification of a New Allelic Variant of the Acinetobacter baumannii Cephalosporinase, ADC-7 -Lactamase: Defining a Unique Family of Class C Enzymes. Antimicrob. Agents Chemother. 2005, 49, 2941-2948. [CrossRef]

103. Héritier, C.; Poirel, L.; Nordmann, P. Cephalosporinase over-expression resulting from insertion of ISAba1 in Acinetobacter baumannii. Clin. Microbiol. Infect. 2006, 12, 123-130. [CrossRef]

104. Lopes, B.S.; Amyes, S.G.B. Role of ISAba1 and ISAba125 in governing the expression of blaADC in clinically relevant Acinetobacter baumannii strains resistant to cephalosporins. J. Med. Microbiol. 2012, 61, 1103-1108. [CrossRef] 
105. Tian, G.-B.; Adams-Haduch, J.M.; Taracila, M.; Bonomo, R.A.; Wang, H.-N.; Doi, Y. Extended-spectrum AmpC cephalosporinase in Acinetobacter baumannii: ADC-56 confers resistance to cefepime. Antimicrob. Agents Chemother. 2011, 55, 4922-4925. [CrossRef]

106. Urban, C.; Go, E.; Mariano, N.; Rahal, J.J. Interaction of sulbactam, clavulanic acid and tazobactam with penicillin-binding proteins of imipenem-resistant and -susceptible Acinetobacter baumannii. FEMS Microbiol. Lett. 1995, 125, 193-197. [CrossRef]

107. Krizova, L.; Poirel, L.; Nordmann, P.; Nemec, A. TEM-1 -lactamase as a source of resistance to sulbactam in clinical strains of Acinetobacter baumannii. J. Antimicrob. Chemother. 2013, 68, 2786-2791. [CrossRef] [PubMed]

108. Higgins, P.G.; Wisplinghoff, H.; Stefanik, D.; Seifert, H. In vitro activities of the beta-lactamase inhibitors clavulanic acid, sulbactam, and tazobactam alone or in combination with beta-lactams against epidemiologically characterized multidrug-resistant Acinetobacter baumannii strains. Antimicrob. Agents Chemother. 2004, 48, 1586-1592. [CrossRef] [PubMed]

109. Giannouli, M.; Di Popolo, A.; Durante-Mangoni, E.; Bernardo, M.; Cuccurullo, S.; Amato, G.; Tripodi, M.-F.; Triassi, M.; Utili, R.; Zarrilli, R. Molecular epidemiology and mechanisms of rifampicin resistance in Acinetobacter baumannii isolates from Italy. Int. J. Antimicrob. Agents 2012, 39, 58-63. [CrossRef] [PubMed]

110. Houang, E.T.S.; Chu, Y.-W.; Lo, W.-S.; Chu, K.-Y.; Cheng, A.F.B. Epidemiology of rifampin ADP-ribosyltransferase (arr-2) and metallo-beta-lactamase (blaIMP-4) gene cassettes in class 1 integrons in Acinetobacter strains isolated from blood cultures in 1997 to 2000. Antimicrob. Agents Chemother. 2003, 47, 1382-1390. [CrossRef] [PubMed]

111. Chopra, I.; Hawkey, P.M.; Hinton, M. Tetracyclines, molecular and clinical aspects. J. Antimicrob. Chemother. 1992, 29, 245-277. [CrossRef]

112. Coyne, S.; Courvalin, P.; Périchon, B. Efflux-Mediated Antibiotic Resistance in Acinetobacter spp. Antimicrob. Agents Chemother. 2011, 55, 947-953. [CrossRef]

113. Hornsey, M.; Ellington, M.J.; Doumith, M.; Thomas, C.P.; Gordon, N.C.; Wareham, D.W.; Quinn, J.; Lolans, K.; Livermore, D.M.; Woodford, N. AdeABC-mediated efflux and tigecycline MICs for epidemic clones of Acinetobacter baumannii. J. Antimicrob. Chemother. 2010, 65, 1589-1593. [CrossRef]

114. Li, J.; Nation, R.L.; Turnidge, J.D.; Milne, R.W.; Coulthard, K.; Rayner, C.R.; Paterson, D.L. Colistin: The re-emerging antibiotic for multidrug-resistant Gram-negative bacterial infections. Lancet Infect. Dis. 2006, 6, 589-601. [CrossRef]

115. CDC Biggest Threats and Data|Antibiotic/Antimicrobial Resistance|CDC. Available online: https://www.cdc. gov/drugresistance/biggest_threats.html (accessed on 8 March 2019).

116. Beceiro, A.; Llobet, E.; Aranda, J.; Bengoechea, J.A.; Doumith, M.; Hornsey, M.; Dhanji, H.; Chart, H.; Bou, G.; Livermore, D.M.; et al. Phosphoethanolamine Modification of Lipid A in Colistin-Resistant Variants of Acinetobacter baumannii Mediated by the pmrAB Two-Component Regulatory System. Antimicrob. Agents Chemother. 2011, 55, 3370-3379. [CrossRef]

117. Arroyo, L.A.; Herrera, C.M.; Fernandez, L.; Hankins, J.V.; Trent, M.S.; Hancock, R.E.W. The pmrCAB Operon Mediates Polymyxin Resistance in Acinetobacter baumannii ATCC 17978 and Clinical Isolates through Phosphoethanolamine Modification of Lipid A. Antimicrob. Agents Chemother. 2011, 55, 3743-3751. [CrossRef] [PubMed]

118. Moffatt, J.H.; Harper, M.; Harrison, P.; Hale, J.D.F.; Vinogradov, E.; Seemann, T.; Henry, R.; Crane, B.; Michael, F.S.; Cox, A.D.; et al. Colistin Resistance in Acinetobacter baumannii Is Mediated by Complete Loss of Lipopolysaccharide Production. Antimicrob. Agents Chemother. 2010, 54, 4971-4977. [CrossRef] [PubMed]

119. Biswas, S.; Brunel, J.-M.; Dubus, J.-C.; Reynaud-Gaubert, M.; Rolain, J.-M. Colistin: An update on the antibiotic of the 21st century. Expert Rev. Anti-infect. Ther. 2012, 10, 917-934. [CrossRef]

120. Esterly, J.S.; Richardson, C.L.; Eltoukhy, N.S.; Qi, C.; Scheetz, M.H. Genetic Mechanisms of Antimicrobial Resistance of Acinetobacter Baumannii. Ann. Pharmacother. 2011, 45, 218-228. [CrossRef]

121. Doi, Y.; Murray, G.; Peleg, A. Acinetobacter baumannii: Evolution of Antimicrobial Resistance-Treatment Options. Semin. Respir. Crit. Care Med. 2015, 36, 085-098.

122. Hasan, M.J.; Shamsuzzaman, S.M. Distribution of adeB and NDM-1 genes in multidrug resistant Acinetobacter baumannii isolated from infected wound of patients admitted in a tertiary care hospital in Bangladesh. Malays. J. Pathol. 2017, 39, 277-283. [PubMed] 
123. Smiline, A.; Vijayashree, J.; Paramasivam, A. Molecular characterization of plasmid-encoded blaTEM, blaSHV and blaCTX-M among extended spectrum $\beta$-lactamases [ESBLs] producing Acinetobacter baumannii. Br. J. Biomed. Sci. 2018, 75, 200-202. [CrossRef]

124. Benmahmod, A.B.; Said, H.S.; Ibrahim, R.H. Prevalence and Mechanisms of Carbapenem Resistance Among Acinetobacter baumannii Clinical Isolates in Egypt. Microb. Drug Resist. 2019, 25, 480-488. [CrossRef]

125. The $10 \times$ '20 Initiative: Pursuing a Global Commitment to Develop 10 New Antibacterial Drugs by 2020. Clin. Infect. Dis. 2010, 50, 1081-1083. [CrossRef]

126. Murray, C.K.; Hospenthal, D.R. Treatment of multidrug resistant Acinetobacter. Curr. Opin. Infect. Dis. 2005, 18, 502-506. [CrossRef]

127. Fournier, P.E.; Richet, H.; Weinstein, R.A. The Epidemiology and Control of Acinetobacter baumannii in Health Care Facilities. Clin. Infect. Dis. 2006, 42, 692-699. [CrossRef] [PubMed]

128. Falagas, M.E.; Kasiakou, S.K.; Rafailidis, P.I.; Zouglakis, G.; Morfou, P. Comparison of mortality of patients with Acinetobacter baumannii bacteraemia receiving appropriate and inappropriate empirical therapy. $J$. Antimicrob. Chemother. 2006, 57, 1251-1254. [CrossRef] [PubMed]

129. Cisneros, J.M.; Rodríguez-Baño, J. Nosocomial bacteremia due to Acinetobacter baumannii: Epidemiology, clinical features and treatment. Clin. Microbiol. Infect. 2002, 8, 687-693. [CrossRef]

130. Wood, G.C.; Hanes, S.D.; Boucher, B.A.; Croce, M.A.; Fabian, T.C. Tetracyclines for treating multidrug-resistant Acinetobacter baumannii ventilator-associated pneumonia. Intensive Care Med. 2003, 29, 2072-2076. [CrossRef]

131. Akers, K.S.; Mende, K.; Yun, H.C.; Hospenthal, D.R.; Beckius, M.L.; Yu, X.; Murray, C.K. Tetracycline susceptibility testing and resistance genes in isolates of Acinetobacter baumannii-Acinetobacter calcoaceticus complex from a U.S. military hospital. Antimicrob. Agents Chemother. 2009, 53, 2693-2695. [CrossRef]

132. Griffith, M.E.; Yun, H.C.; Horvath, L.L.; Murray, C.K. Minocycline Therapy for Traumatic Wound Infections Caused by the Multidrug-Resistant Acinetobacter baumannii-Acinetobacter calcoaceticus Complex. Infect. Dis. Clin. Pract. 2008, 16, 16-19. [CrossRef]

133. Nepka, M.; Perivolioti, E.; Kraniotaki, E.; Politi, L.; Tsakris, A.; Pournaras, S. In Vitro Bactericidal Activity of Trimethoprim-Sulfamethoxazole Alone and in Combination with Colistin against Carbapenem-Resistant Acinetobacter baumannii Clinical Isolates. Antimicrob. Agents Chemother. 2016, 60, 6903-6906. [CrossRef]

134. Greer, N.D. Tigecycline (Tygacil): The first in the glycylcycline class of antibiotics. Proceedings (Bayl. Univ. Med. Cent.) 2006, 19, 155-161. [CrossRef]

135. Necati Hakyemez, I.; Kucukbayrak, A.; Tas, T.; Burcu Yikilgan, A.; Akkaya, A.; Yasayacak, A.; Akdeniz, H. Nosocomial Acinetobacter baumannii Infections and Changing Antibiotic Resistance. Pakistan J. Med. Sci. 2013, 29, 1245-1248.

136. Batirel, A.; Balkan, I.I.; Karabay, O.; Agalar, C.; Akalin, S.; Alici, O.; Alp, E.; Altay, F.A.; Altin, N.; Arslan, F.; et al. Comparison of colistin-carbapenem, colistin-sulbactam, and colistin plus other antibacterial agents for the treatment of extremely drug-resistant Acinetobacter baumannii bloodstream infections. Eur. J. Clin. Microbiol. Infect. Dis. 2014, 33, 1311-1322. [CrossRef]

137. Temocin, F.; Erdinc, F.S.; Tulek, N.; Demirelli, M.; Ertem, G.; Kinikli, S.; Koksal, E. Synergistic effects of sulbactam in multi-drug-resistant Acinetobacter baumannii. Braz. J. Microbiol. 2015, 46, 1119-1124. [CrossRef] [PubMed]

138. Pachón-Ibáñez, M.E.; Docobo-Pérez, F.; López-Rojas, R.; Domínguez-Herrera, J.; Jiménez-Mejias, M.E.; García-Curiel, A.; Pichardo, C.; Jiménez, L.; Pachón, J. Efficacy of rifampin and its combinations with imipenem, sulbactam, and colistin in experimental models of infection caused by imipenem-resistant Acinetobacter baumannii. Antimicrob. Agents Chemother. 2010, 54, 1165-1172. [CrossRef] [PubMed]

139. Liang, W.; Liu, X.; Huang, J.; Zhu, D.; Li, J.; Zhang, J. Activities of colistin- and minocycline-based combinations against extensive drug resistant Acinetobacter baumannii isolates from intensive care unit patients. BMC Infect. Dis. 2011, 11, 109. [CrossRef] [PubMed]

140. Liu, X.; Zhao, M.; Chen, Y.; Bian, X.; Li, Y.; Shi, J.; Zhang, J. Synergistic killing by meropenem and colistin combination of carbapenem-resistant Acinetobacter baumannii isolates from Chinese patients in an in vitro pharmacokinetic/pharmacodynamic model. Int. J. Antimicrob. Agents 2016, 48, 559-563. [CrossRef]

141. Principe, L.; D'Arezzo, S.; Capone, A.; Petrosillo, N.; Visca, P. In vitro activity of tigecycline in combination with various antimicrobials against multidrug resistant Acinetobacter baumannii. Ann. Clin. Microbiol. Antimicrob. 2009, 8, 18. [CrossRef] [PubMed] 
142. Lee, H.J.; Choi, J.Y.; Kang, C.-I.; Park, D.W.; Kim, M.J.; Peck, K.R.; Lee, M.S.; Kim, H.S.; Ko, K.S.; Cho, Y.K. In vitro time-kill studies of antimicrobial agents against blood isolates of imipenem-resistant Acinetobacter baumannii, including colistin- or tigecycline-resistant isolates. J. Med. Microbiol. 2012, 61, 353-360.

143. Aydemir, H.; Akduman, D.; Piskin, N.; Comert, F.; Horuz, E.; Terzi, A.; Kokturk, F.; Ornek, T.; Celebi, G. Colistin vs. the combination of colistin and rifampicin for the treatment of carbapenem-resistant Acinetobacter baumannii ventilator-associated pneumonia. Epidemiol. Infect. 2013, 141, 1214-1222. [CrossRef] [PubMed]

144. Cirioni, O.; Simonetti, O.; Pierpaoli, E.; Barucca, A.; Ghiselli, R.; Orlando, F.; Pelloni, M.; Trombettoni, M.M.C.; Guerrieri, M.; Offidani, A.; et al. Colistin enhances therapeutic efficacy of daptomycin or teicoplanin in a murine model of multiresistant Acinetobacter baumannii sepsis. Diagn. Microbiol. Infect. Dis. 2016, 86, 392-398. [CrossRef]

145. Bowler, S.L.; Spychala, C.N.; McElheny, C.L.; Mettus, R.T.; Doi, Y. In Vitro Activity of Fusidic Acid-Containing Combinations against Carbapenem-Resistant Acinetobacter baumannii Clinical Strains. Antimicrob. Agents Chemother. 2016, 60, 5101. [CrossRef]

146. Wareham, D.W.; Gordon, N.C.; Hornsey, M. In vitro activity of teicoplanin combined with colistin versus multidrug-resistant strains of Acinetobacter baumannii. J. Antimicrob. Chemother. 2011, 66, 1047-1051. [CrossRef]

147. Jeon, J.; Ryu, C.-M.; Lee, J.-Y.; Park, J.-H.; Yong, D.; Lee, K. In Vivo Application of Bacteriophage as a Potential Therapeutic Agent To Control OXA-66-Like Carbapenemase-Producing Acinetobacter baumannii Strains Belonging to Sequence Type 357. Appl. Environ. Microbiol. 2016, 82, 4200-4208. [CrossRef] [PubMed]

148. Hua, Y.; Luo, T.; Yang, Y.; Dong, D.; Wang, R.; Wang, Y.; Xu, M.; Guo, X.; Hu, F.; He, P. Phage Therapy as a Promising New Treatment for Lung Infection Caused by Carbapenem-Resistant Acinetobacter baumannii in Mice. Front. Microbiol. 2018, 8, 2659. [CrossRef] [PubMed]

149. Lee, C.-R.; Lee, J.H.; Park, M.; Park, K.S.; Bae, I.K.; Kim, Y.B.; Cha, C.-J.; Jeong, B.C.; Lee, S.H. Biology of Acinetobacter baumannii: Pathogenesis, Antibiotic Resistance Mechanisms, and Prospective Treatment Options. Front. Cell. Infect. Microbiol. 2017, 7, 55. [CrossRef] [PubMed]

150. Sun, L.; Wang, X.; Li, Z. Successful treatment of multidrug-resistant Acinetobacter baumannii meningitis with ampicillin sulbactam in primary hospital. Br. J. Neurosurg. 2018, 32, 642-645. [CrossRef] [PubMed]

151. Özbek, B.; Şentürk, A. Postantibiotic Effects of Tigecycline, Colistin Sulfate, and Levofloxacin Alone or Tigecycline-Colistin Sulfate and Tigecycline-Levofloxacin Combinations against Acinetobacter baumannii. Chemotherapy 2010, 56, 466-471. [CrossRef]

152. Sheng, W.-H.; Wang, J.-T.; Li, S.-Y.; Lin, Y.-C.; Cheng, A.; Chen, Y.-C.; Chang, S.-C. Comparative in vitro antimicrobial susceptibilities and synergistic activities of antimicrobial combinations against carbapenem-resistant Acinetobacter species: Acinetobacter baumannii versus Acinetobacter genospecies 3 and 13TU. Diagn. Microbiol. Infect. Dis. 2011, 70, 380-386. [CrossRef]

153. Fan, B.; Guan, J.; Wang, X.; Cong, Y. Activity of Colistin in Combination with Meropenem, Tigecycline, Fosfomycin, Fusidic Acid, Rifampin or Sulbactam against Extensively Drug-Resistant Acinetobacter baumannii in a Murine Thigh-Infection Model. PLoS ONE 2016, 11, e0157757. [CrossRef]

154. Paterson, D.L.; Doi, Y. Optimal Therapy for Multidrug-Resistant Acinetobacter baumannii. Emerg. Infect. Dis. 2010, 16, 171. [CrossRef]

155. Sheng, W.-H.; Liao, C.-H.; Lauderdale, T.-L.; Ko, W.-C.; Chen, Y.-S.; Liu, J.-W.; Lau, Y.-J.; Wang, L.-S.; Liu, K.-S.; Tsai, T.-Y.; et al. A multicenter study of risk factors and outcome of hospitalized patients with infections due to carbapenem-resistant Acinetobacter baumannii. Int. J. Infect. Dis. 2010, 14, 764-769. [CrossRef]

156. Yang, Y.; Bhachech, N.; Bush, K. Biochemical comparison of imipenem, meropenem and biapenem: Permeability, binding to penicillin-binding proteins, and stability to hydrolysis by $\beta$-lactamases. J. Antimicrob. Chemother. 1995, 35, 75-84. [CrossRef]

157. Labia, R.; Morand, A.; Guionie, M. ß-Lactamase stability of imipenem. J. Antimicrob. Chemother. 1986, 18, 1-8. [CrossRef] [PubMed]

158. Edwards, J.R.; Turner, P.J.; Wannop, C.; Withnell, E.S.; Grindey, A.J.; Nairn, K. In vitro antibacterial activity of SM-7338, a carbapenem antibiotic with stability to dehydropeptidase I. Antimicrob. Agents Chemother. 1989, 33, 215-222. [CrossRef] [PubMed]

159. Brauers, J.; Frank, U.; Kresken, M.; Rodloff, A.C.; Seifert, H. Activities of various $\beta$-lactams and $\beta$-lactam/ $\beta$-lactamase inhibitor combinations against Acinetobacter baumannii and Acinetobacter DNA group 3 strains. Clin. Microbiol. Infect. 2005, 11, 24-30. [CrossRef] [PubMed] 
160. Wood, G.C.; Hanes, S.D.; Croce, M.A.; Fabian, T.C.; Boucher, B.A. Comparison of Ampicillin-Sulbactam and Imipenem-Cilastatin for the Treatment of Acinetobacter Ventilator-Associated Pneumonia. Clin. Infect. Dis. 2002, 34, 1425-1430. [CrossRef] [PubMed]

161. Smolyakov, R.; Borer, A.; Riesenberg, K.; Schlaeffer, F.; Alkan, M.; Porath, A.; Rimar, D.; Almog, Y.; Gilad, J. Nosocomial multi-drug resistant Acinetobacter baumannii bloodstream infection: Risk factors and outcome with ampicillin-sulbactam treatment. J. Hosp. Infect. 2003, 54, 32-38. [CrossRef]

162. Rodriguez-Hernandez, M.-J.; Pachon, J.; Pichardo, C.; Cuberos, L.; Ibanez-Martinez, J.; Garcia-Curiel, A.; Caballero, F.J.; Moreno, I.; Jimenez-Mejias, M.E. Imipenem, doxycycline and amikacin in monotherapy and in combination in Acinetobacter baumannii experimental pneumonia. J. Antimicrob. Chemother. 2000, 45, 493-501. [CrossRef]

163. Holloway, K.P.; Rouphael, N.G.; Wells, J.B.; King, M.D.; Blumberg, H.M. Polymyxin B and Doxycycline Use in Patients with Multidrug-Resistant Acinetobacter baumannii Infections in the Intensive Care Unit. Ann. Pharmacother. 2006, 40, 1939-1945. [CrossRef]

164. Pachón-Ibáñez, M.E.; Jiménez-Mejías, M.E.; Pichardo, C.; Llanos, A.C.; Pachón, J. Activity of tigecycline (GAR-936) against Acinetobacter baumannii strains, including those resistant to imipenem. Antimicrob. Agents Chemother. 2004, 48, 4479-4481. [CrossRef]

165. Tutuncu, E.E.; Kuscu, F.; Gurbuz, Y.; Ozturk, B.; Haykir, A.; Sencan, I. Tigecycline use in two cases with multidrug-resistant Acinetobacter baumannii meningitis. Int. J. Infect. Dis. 2010, 14, e224-e226. [CrossRef]

166. Sader, H.S.; Jones, R.N.; Dowzicky, M.J.; Fritsche, T.R. Antimicrobial activity of tigecycline tested against nosocomial bacterial pathogens from patients hospitalized in the intensive care unit. Diagn. Microbiol. Infect. Dis. 2005, 52, 203-208. [CrossRef]

167. Walkty, A.; DeCorby, M.; Nichol, K.; Karlowsky, J.A.; Hoban, D.J.; Zhanel, G.G. In vitro activity of colistin (polymyxin E) against 3,480 isolates of gram-negative bacilli obtained from patients in Canadian hospitals in the CANWARD study, 2007-2008. Antimicrob. Agents Chemother. 2009, 53, 4924-4926. [CrossRef] [PubMed]

168. Lin, M.-F.; Lan, C.-Y. Antimicrobial resistance in Acinetobacter baumannii: From bench to bedside. World J. Clin. Cases 2014, 2, 787-814. [CrossRef] [PubMed]

169. Velkov, T.; Roberts, K.D.; Nation, R.L.; Thompson, P.E.; Li, J. Pharmacology of polymyxins: New insights into an "old" class of antibiotics. Future Microbiol. 2013, 8, 711-724. [CrossRef]

170. Sampson, T.R.; Liu, X.; Schroeder, M.R.; Kraft, C.S.; Burd, E.M.; Weiss, D.S. Rapid killing of Acinetobacter baumannii by polymyxins is mediated by a hydroxyl radical death pathway. Antimicrob. Agents Chemother. 2012, 56, 5642-5649. [CrossRef] [PubMed]

171. Kohanski, M.A.; Dwyer, D.J.; Hayete, B.; Lawrence, C.A.; Collins, J.J. A Common Mechanism of Cellular Death Induced by Bactericidal Antibiotics. Cell 2007, 130, 797-810. [CrossRef] [PubMed]

172. Yu, Z.; Qin, W.; Lin, J.; Fang, S.; Qiu, J. Antibacterial Mechanisms of Polymyxin and Bacterial Resistance. Biomed. Res. Int. 2015, 2015, 1-11. [CrossRef] [PubMed]

173. Sandri, A.M.; Landersdorfer, C.B.; Jacob, J.; Boniatti, M.M.; Dalarosa, M.G.; Falci, D.R.; Behle, T.F.; Bordinhão, R.C.; Wang, J.; Forrest, A.; et al. Population Pharmacokinetics of Intravenous Polymyxin B in Critically Ill Patients: Implications for Selection of Dosage Regimens. Clin. Infect. Dis. 2013, 57, 524-531. [CrossRef] [PubMed]

174. Bassetti, M.; Repetto, E.; Righi, E.; Boni, S.; Diverio, M.; Molinari, M.P.; Mussap, M.; Artioli, S.; Ansaldi, F.; Durando, P.; et al. Colistin and rifampicin in the treatment of multidrug-resistant Acinetobacter baumannii infections. J. Antimicrob. Chemother. 2007, 61, 417-420. [CrossRef]

175. Bae, S.; Kim, M.-C.; Park, S.-J.; Kim, H.S.; Sung, H.; Kim, M.-N.; Kim, S.-H.; Lee, S.-O.; Choi, S.-H.; Woo, J.H.; et al. In Vitro Synergistic Activity of Antimicrobial Agents in Combination against Clinical Isolates of Colistin-Resistant Acinetobacter baumannii. Antimicrob. Agents Chemother. 2016, 60, 6774-6779. [CrossRef]

176. Qureshi, Z.A.; Hittle, L.E.; O’Hara, J.A.; Rivera, J.I.; Syed, A.; Shields, R.K.; Pasculle, A.W.; Ernst, R.K.; Doi, Y. Colistin-Resistant Acinetobacter baumannii: Beyond Carbapenem Resistance. Clin. Infect. Dis. An Off. Publ. Infect. Dis. Soc. Am. 2015, 60, 1295. [CrossRef] [PubMed]

177. Hong, Y.-K.; Lee, J.-Y.; Wi, Y.M.; Ko, K.S. High rate of colistin dependence in Acinetobacter baumannii. J. Antimicrob. Chemother. 2016, 71, 2346-2348. [CrossRef] [PubMed]

178. Dubrovskaya, Y.; Prasad, N.; Lee, Y.; Esaian, D.; Figueroa, D.A.; Tam, V.H. Risk factors for nephrotoxicity onset associated with polymyxin B therapy. J. Antimicrob. Chemother. 2015, 70, 1903-1907. [CrossRef] [PubMed] 
179. Hagihara, M.; Housman, S.T.; Nicolau, D.P.; Kuti, J.L. In vitro pharmacodynamics of polymyxin B and tigecycline alone and in combination against carbapenem-resistant Acinetobacter baumannii. Antimicrob. Agents Chemother. 2014, 58, 874-879. [CrossRef] [PubMed]

180. Rao, G.G.; Ly, N.S.; Bulitta, J.B.; Soon, R.L.; San Roman, M.D.; Holden, P.N.; Landersdorfer, C.B.; Nation, R.L.; Li, J.; Forrest, A.; et al. Polymyxin B in combination with doripenem against heteroresistant Acinetobacter baumannii: Pharmacodynamics of new dosing strategies. J. Antimicrob. Chemother. 2016, 71, 3148-3156. [CrossRef] [PubMed]

181. Bergen, P.J.; Bulman, Z.P.; Landersdorfer, C.B.; Smith, N.; Lenhard, J.R.; Bulitta, J.B.; Nation, R.L.; Li, J.; Tsuji, B.T. Optimizing Polymyxin Combinations Against Resistant Gram-Negative Bacteria. Infect. Dis. Ther. 2015, 4, 391-415. [CrossRef]

182. Hitchings, G.H. Mechanism of Action of Trimethoprim-Sulfamethoxazole-I. J. Infect. Dis. 1973, 128, S433-S436. [CrossRef]

183. Burchall, J.J. Mechanism of Action of Trimethoprim-Sulfamethoxazole-II. J. Infect. Dis. 1973, 128, S437-S441. [CrossRef]

184. Schooley, R.T.; Biswas, B.; Gill, J.J.; Hernandez-Morales, A.; Lancaster, J.; Lessor, L.; Barr, J.J.; Reed, S.L.; Rohwer, F.; Benler, S.; et al. Development and Use of Personalized Bacteriophage-Based Therapeutic Cocktails To Treat a Patient with a Disseminated Resistant Acinetobacter baumannii Infection. Antimicrob. Agents Chemother. 2017, 61, e00954-17. [CrossRef]

185. Schmelcher, M.; Donovan, D.M.; Loessner, M.J. Bacteriophage endolysins as novel antimicrobials. Future Microbiol. 2012, 7, 1147-1171. [CrossRef]

186. Briers, Y.; Walmagh, M.; Van Puyenbroeck, V.; Cornelissen, A.; Cenens, W.; Aertsen, A.; Oliveira, H.; Azeredo, J.; Verween, G.; Pirnay, J.-P.; et al. Engineered endolysin-based "Artilysins" to combat multidrug-resistant gram-negative pathogens. MBio 2014, 5, e01379-14. [CrossRef]

187. Huang, G.; Shen, X.; Gong, Y.; Dong, Z.; Zhao, X.; Shen, W.; Wang, J.; Hu, F.; Peng, Y. Antibacterial properties of Acinetobacter baumanniiphage Abp1 endolysin (PlyAB1). BMC Infect. Dis. 2014, 14, 681. [CrossRef] [PubMed]

(C) 2020 by the authors. Licensee MDPI, Basel, Switzerland. This article is an open access article distributed under the terms and conditions of the Creative Commons Attribution (CC BY) license (http://creativecommons.org/licenses/by/4.0/). 